\title{
Weed species diversity in cropping systems: Management and conservation strategies
}

\author{
Dissertation \\ zur Erlangung des Doktorgrades \\ der Fakultät für Agrarwissenschaften \\ der Georg-August-Universität Göttingen
}

vorgelegt von

Lena Ulber

geboren in Göttingen

Göttingen, April 2010 
D 7

1. Referent: Prof. Dr. Johannes Isselstein

2. Korreferentin: Prof. Dr. Bärbel Gerowitt

Tag der mündlichen Prüfung: 12.05.2010 


\section{Contents}

Chapter 1: General introduction........................................................................................1

Weed species diversity in cropping systems: Management and conservation

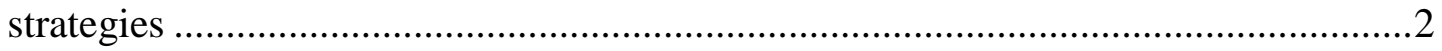

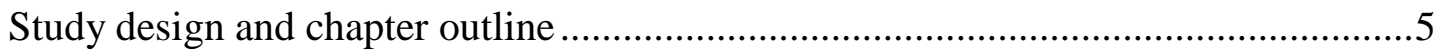

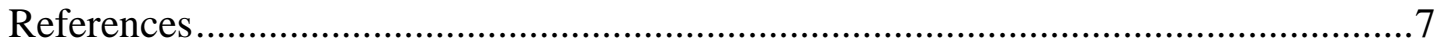

Chapter 2: An experimental on-farm approach to investigate the impact of diversified crop rotations on weed species richness and composition in winter wheat ..........................................................................................................12

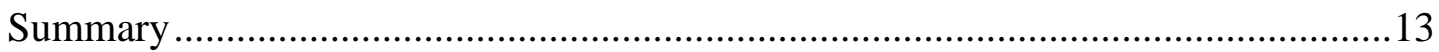

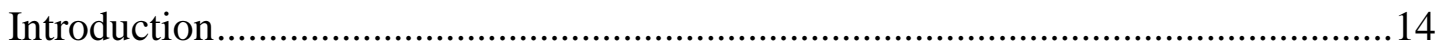

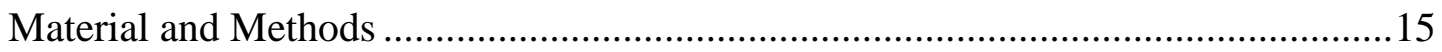

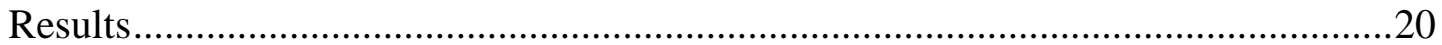

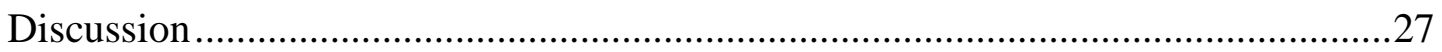

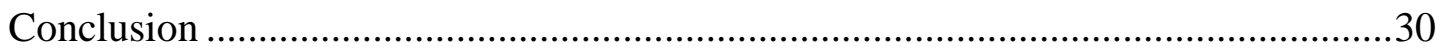

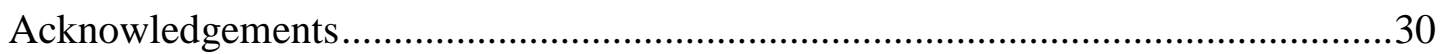

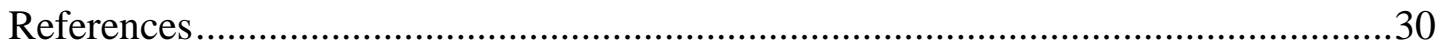

Chapter 3: Using selective herbicides to manage beneficial and rare weed species in winter wheat.....................................................................................................................334

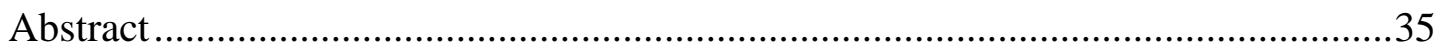

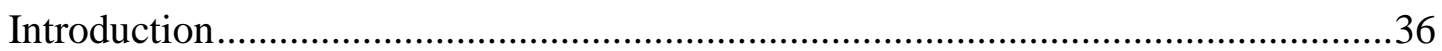

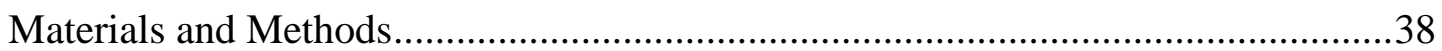

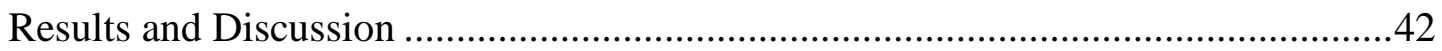

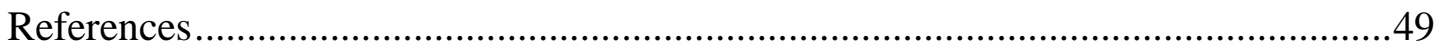

Chapter 4: Implementing conservation auctions to pay farmers for delivering environmental services..........................................................................53

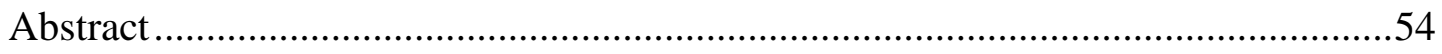

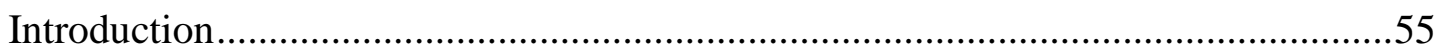

Design and implementation of the PES scheme .................................................57

Evaluating the performance of the PES scheme .....................................................59

Does the PES scheme achieve additionality in service provision? ...........................60

Do bid prices in a conservation auction reflect farmers' opportunity costs?.............61

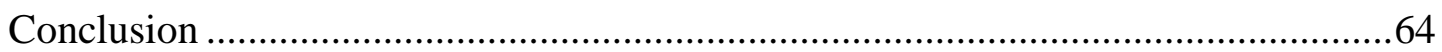

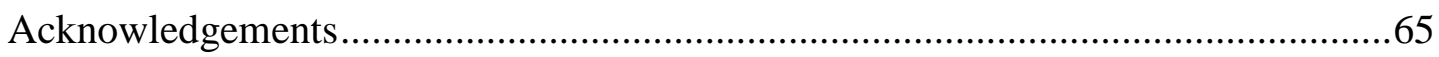

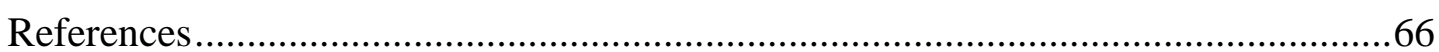


Chapter 5: Discussion \& Conclusion ............................................................................69

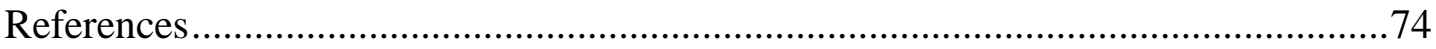

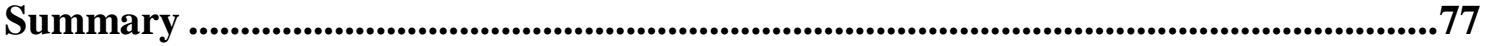

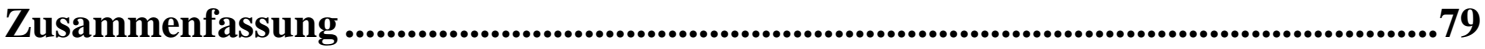

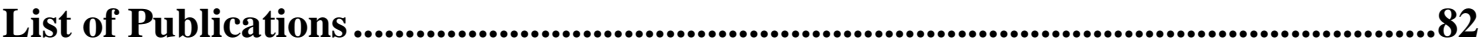

Acknowledgements ..........................................................................................................................884

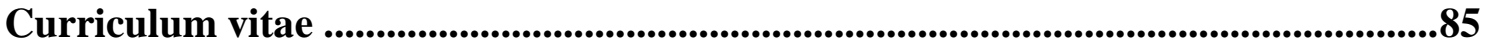




\section{Chapter}

1

General introduction 


\section{Weed species diversity in cropping systems: Management and conservation strategies}

During recent decades, weed species diversity in agricultural landscapes has declined mainly due to intensification of farming practices accompanied by simplification of crop rotations, increased nitrogen fertilisation rates and weed control by highly effective herbicides (Aebischer, 1991; Hyvönen \& Salonen, 2002; Robinson \& William, 2002; Håkansson, 2003; Potts et al., 2010). However, recent studies have indicated that increased weed diversity may have a positive impact on the functioning of agro-ecosystems (Albrecht, 2003; Norris \& Kogan, 2005; Franke et al., 2009). In this context, weeds have been found to support beneficial ecological services such as pollination activity (Gabriel \& Tscharntke, 2006) and prevention of soil erosion (Weil, 1982). Moreover, there is evidence that weeds may act as a direct host plant for many phytophagous insect species, some of which might be an important food source for farmland birds (Sotherton et al., 1985; Altieri, 1999; Marshall et al., 2003; Storkey \& Westbury, 2007), and provide habitat, feeding and reproduction sites for natural enemies of pests (Schellhorn \& Sork, 1997; Nentwig et al., 1998). Individual weed species are known to differ in their ecological function in terms of providing resources for beneficial invertebrates and seedeating birds (Hawes et al., 2003; Storkey, 2006) as well as in their impediment to crop production (Boatman et al., 2003; Storkey \& Westbury, 2007). However, by competing for light and nutrient resources and by reducing crop yields and quality, many weed species such as Galium aparine and Alopecurus myosuroides represent a constant threat to crop productivity if not adequately controlled (Liebman, 2001). A new approach to biodiversityfriendly weed management is therefore intentional to enhance beneficial functions derived from weeds by maintaining desirable species with high value for the agro-ecosystem and, at the same time, providing sufficient control of undesirable, highly competitive species (Liebman, 2001; Marshall et al., 2003; Storkey \& Westbury, 2007).

In agricultural systems, crop management practices act as direct filters determining the diversity and composition of weed species (Cardina et al., 2002; Marshall et al., 2003). Numerous studies quantifying the impact of management and farming system on arable biodiversity have proven that organic systems show both higher weed species richness of the above ground vegetation (Hald, 1999; Bengtsson et al., 2005; Hole et al., 2005; Roschewitz et al., 2005) and the soil seedbank (Menalled et al., 2001) compared with conventional farming systems. Besides organic farming systems, conventional farming systems also show substantial variation in their relative influence on weed species diversity 
and community composition (Bàrberi et al., 1997; Doucet et al., 1999; Hald, 1999). Currently, high-yielding temperate cropping systems are characterised by only a limited number of crop species in crop rotations and a high input of herbicides effective on a wide range of weed taxa (Sutcliffe \& Kay, 2000; Hyvönen \& Salonen, 2002; Smith \& Gross, 2007). Against this background, diversified crop rotations have been suggested to enhance weed species diversity by creating niches for a wide range of weed species through different crop sowing times, varying crop life cycles and multiple options for mechanical and chemical weed control (Liebman \& Dyck, 1993; Clements et al., 1994; Cardina et al., 2002; Légère \& Samson, 2004; Rasmussen et al., 2006). Current herbicides used for chemical weed control in cropping systems differ in terms of active ingredients and mode of action. In addition, weed species also vary in susceptibility against these herbicides. The use of selective narrow-spectrum herbicides that are intrinsically less effective against some desirable broad-leaved weed species have therefore been put forward as an important in-crop management technique, targeted at increasing the ecological benefits provided by weed species (Boatman et al., 1999; Liebman, 2001; Lutman, 2005; Jones \& Smith, 2007; Smith et al., 2009). Consequently, by selectively controlling highly competitive species, a balance might be achieved between a satisfactory level of crop productivity, adequate weed control and the requirement for some species to support diversity at higher trophic levels.

Cropping practices adapted to the conservation of weed species diversity within the cropped body of the field are often associated with a loss of farm income caused by lower yields, reduced quality and interference with harvest operations (Storkey \& Westbury, 2007). Therefore, conservation payment schemes have been designed to compensate farmers for the loss of income associated with biodiversity-friendly crop management (Knop et al., 2006). By creating economic incentives for biodiversity enhancement, conservation schemes aim at counteracting the adverse effects of intensive cropping systems on biodiversity (Hyvönen \& Huusela-Veistola, 2008). In this context, incentivebased instruments such as performance payments for environmental services (PES) are increasingly used as a policy instrument for creating economic incentives for the provision of biodiversity (Ferraro, 2001; Ferraro \& Kiss, 2002; Balmford et al., 2002; Wunder et al., 2008 Ten Brink et al., 2009). In PES schemes, payments are directly linked to the provision of a pre-defined environmental service such as weed species diversity. Farmers as service providers are allowed to choose between different management approaches to the conservation of weed diversity on their land. Opportunity costs for the 
provision of an environmental service thus vary dependant on the conducted management and site-specific conditions. In this context, conservation auctions have been suggested to provide biodiversity enhancement for a limited predetermined budget more cost-effective than commonly used fixed-price payments (Naidoo et al., 2006; Schilizzi \& LataczLohmann, 2007).

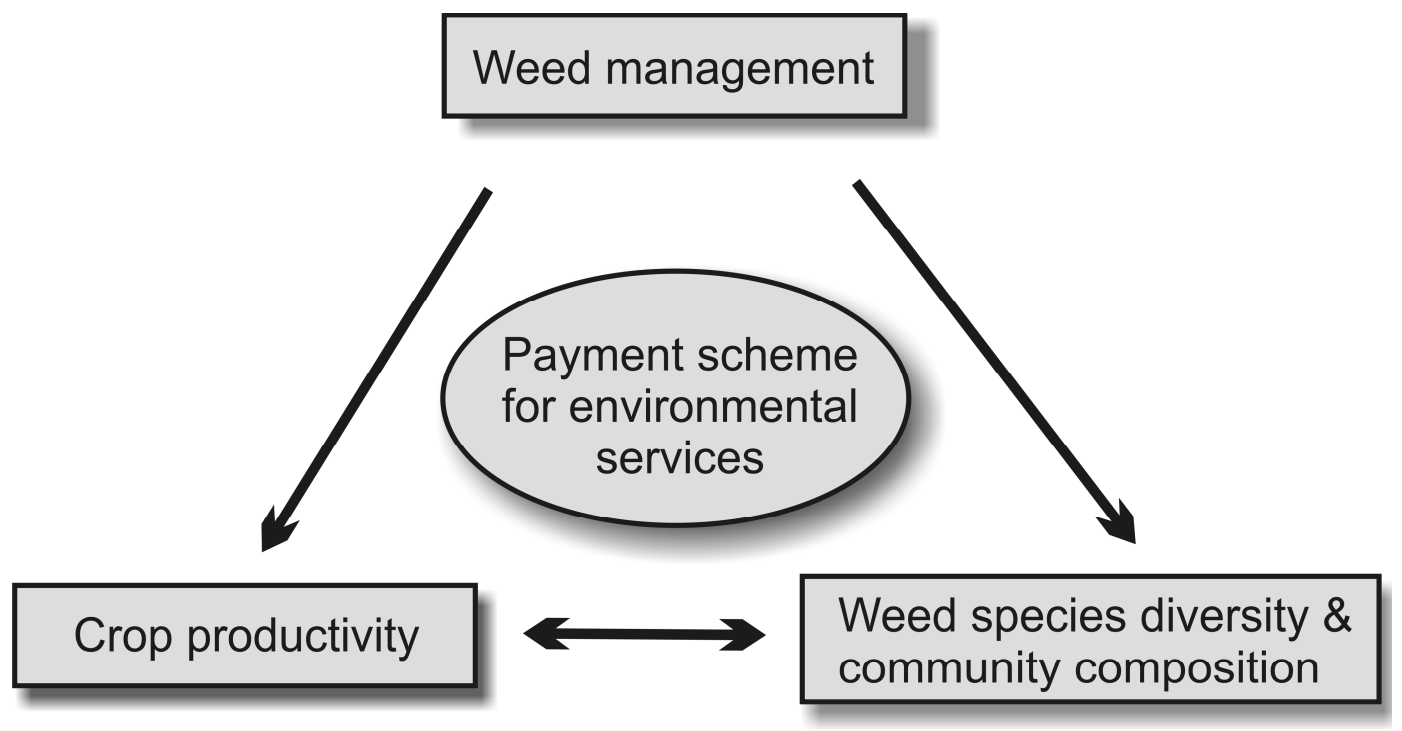

Fig. 1.1 The general topics and interactions covered in the thesis.

As described above, weed management impacts on both crop productivity and weed species diversity (Fig. 1.1). Changes in weed species diversity are further more interrelated to crop productivity. Payment schemes targeted at weed diversity conservation therefore need to provide financial incentives to farmers to compensate them for any income foregone that might result from reduced crop productivity. By combining an assessment of the effects of weed management strategies with an evaluation of a transdiciplinary PES scheme for arable plant diversity, the objectives of the present thesis were as follows:

(1) to evaluate the impact of crop rotation intensity and weed control treatment, in particular in conventional winter wheat cropping systems, on weed species richness, community composition and crop yield,

(2) to test the application of selective herbicides with a narrow weed-control spectrum as a tool for retention of beneficial and rare weed species and control of highly competitive species in winter wheat and

(3) to assess both the ecological effectiveness of an incentive-based PES scheme for conservation of weed species diversity as well as the potential of the scheme to be costeffective. 


\section{Study design and chapter outline}

All studies were conducted in the administrative district of Northeim located in Lower Saxony, Germany. The Northeim district covers an area of c. $1260 \mathrm{~km}^{2}$ (approximate north-south boundaries $51^{\circ} 95^{\prime} \mathrm{N}$ to $51^{\circ} 61^{\prime} \mathrm{N}$ ). The mean annual temperature is $8.7^{\circ} \mathrm{C}$, and the annual precipitation averages $645 \mathrm{~mm}$. The district is dominated by agricultural land use, covering c. $38 \%$ of the region, and large contiguous forest-covered areas in the hilly regions.

In the following section, the main objectives, methods and hypotheses of this thesis are outlined. Chapter 2 to chapter 4 present the experimental and observational studies conducted within the framework of this thesis. A summary of the investigated variables and utilised methods is compiled in Table 1.1. Finally in chapter 5, the results of the conducted studies are jointly discussed and general conclusions are drawn.

Table 1.1 A summary of the investigated predictor and response variables and methods employed within the studies presented in chapter 2 to chapter 4.

\begin{tabular}{|c|c|c|c|c|c|}
\hline & \multirow[b]{2}{*}{$\begin{array}{l}\text { Predictor } \\
\text { variable }\end{array}$} & \multirow[b]{2}{*}{$\begin{array}{l}\text { Response } \\
\text { variables }\end{array}$} & \multicolumn{3}{|c|}{ Methods } \\
\hline & & & $\begin{array}{l}\text { No. of } \\
\text { study } \\
\text { sites }\end{array}$ & $\begin{array}{l}\text { Experimental } \\
\text { methods }\end{array}$ & $\begin{array}{l}\text { Statistical } \\
\text { methods }\end{array}$ \\
\hline Chapter 2 & $\begin{array}{l}\text { Crop } \\
\text { rotation } \\
\text { intensity, } \\
\text { Weed } \\
\text { control } \\
\text { treatment }\end{array}$ & $\begin{array}{l}\text { Species richness, } \\
\text { Weed cover, } \\
\text { Community } \\
\text { composition, } \\
\text { Winter wheat } \\
\text { grain yield }\end{array}$ & 24 & $\begin{array}{l}\text { Triplet design: } \\
\text { Weed assessment } \\
\text { plots: } 100 \mathrm{~m}^{2}, \\
\text { Crop assessment } \\
\text { plots: } 0.25 \mathrm{~m}^{2}\end{array}$ & $\begin{array}{l}\text { Linear mixed- } \\
\text { effects models, } \\
\text { Redundancy } \\
\text { analysis } \\
\text { (RDA) }\end{array}$ \\
\hline Chapter 3 & $\begin{array}{l}\text { Selective } \\
\text { herbicides, } \\
\text { Dose rate }\end{array}$ & $\begin{array}{l}\text { Species richness, } \\
\text { Weed cover, } \\
\text { Community } \\
\text { composition, } \\
\text { Winter wheat } \\
\text { grain yield }\end{array}$ & 2 & $\begin{array}{l}\text { Randomised } \\
\text { block design: } \\
\text { Weed assessment } \\
\text { plots: } 0.1 \mathrm{~m}^{2}, \\
\text { Crop assessment } \\
\text { plots: } 0.25 \mathrm{~m}^{2}\end{array}$ & $\begin{array}{l}\text { Linear mixed- } \\
\text { effects models, } \\
\text { Principle } \\
\text { Response } \\
\text { Curves (PRC) }\end{array}$ \\
\hline Chapter 4 & $\begin{array}{l}\text { Payment } \\
\text { scheme for } \\
\text { environ- } \\
\text { mental } \\
\text { services } \\
\text { (PES) }\end{array}$ & $\begin{array}{l}\text { Species richness, } \\
\text { Opportunity costs, } \\
\text { Bid prices }\end{array}$ & 28 & $\begin{array}{l}\text { Observational } \\
\text { study: } \\
\text { Weed assessment } \\
\text { plots: } 100 \mathrm{~m}^{2}, \\
\text { Farmer surveys }\end{array}$ & $\begin{array}{l}\text { Descriptive } \\
\text { analysis }\end{array}$ \\
\hline
\end{tabular}

In chapter 2, the relative importance of crop rotation intensity and weed control treatment on weed species richness and community composition was experimentally analysed in winter wheat. In addition, it was investigated how weed species of high biodiversity value 
but low competitive ability responded to both experimental factors. Using an on-farm approach, 24 fields of winter wheat related to three crop rotation intensities were sampled: organic crop rotation, conventional simple crop rotation with less than three autumn-sown crop species and conventional diverse crop rotation with three to five crop species, including spring-sown crops. All 24 fields were grouped into eight triplets, each consisting of three fields belonging to one of the three types of crop rotation intensity. In the centre of each field, two paired plots were established. One of the sub-plots received no weed control treatment. Generally, weed species richness was expected to be higher under organic farming compared to conventional farming practice. The experimental factors were therefore designed specifically to test the following hypotheses: (i) fields from conventional diverse crop rotation show higher weed species richness than fields from conventional simple crop rotation; (ii) weed control treatments reduce weed species richness independently of the level of crop rotation intensity.

In chapter 3, the use of selective narrow-spectrum herbicides was evaluated as a potential tool for sustaining desirable weed species while controlling highly competitive pernicious weed species. The experiment was conducted in two winter wheat fields on conventionally managed arable farms in the study region. Both selected fields were chosen with respect to a relatively high abundance of the desirable weed species Centaureacyanus and Papaver rhoeas as well as the pernicious species Galium aparine. The effect of three different herbicide products applied at two dose rates on weed cover and winter wheat crop yield was tested during the growing period. Treatment-induced changes within the weed communities were investigated by means of multivariate principle response curves. It was hypothesized that the application of selective herbicides which are intrinsically less active on particular weed species allows for (i) retention of beneficial or rare species and (ii) control of highly competitive undesirable species.

In chapter 4, both the ecological effectiveness of an incentive-based PES scheme for conservation of weed species diversity and the potential of the scheme to be cost-effective was investigated. The investigations were part of a transdisciplinary research project on the implementation of an incentive-based payment for environmental services (PES) scheme by means of an auction mechanism. Within the conducted PES case-study, the desired environmental service was defined as a predetermined threshold of weed species number that needed to be present on the arable fields. Participating farmers received a payment only if the predefined threshold of weed species diversity was achieved. In the conducted 
auctions, each farmer submitted a sealed bid with an associated payment he would be willing to accept for the provision of the predefined environmental service. In this context, auction theory assumes that farmers' bid prices reflect his opportunity costs arising from the provision of the environmental service (Connor et al., 2008). In order to contribute to the current debate on PES scheme effectiveness, two critical key characteristics related to PES program design and implementation were particularly analysed. Firstly, the characteristic of additionality (Wunder et al., 2008) was addressed by assessing whether the implemented PES scheme resulted in an increase in biodiversity provision by inducing actual management changes. Field pairs grown with winter wheat were composed which comprised a field subscribed to the scheme (PES field) and a conventionally managed field from the same farmer used as a control (reference field). Weed species number was assessed at both PES and reference fields. Secondly, farmers' opportunity costs that resulted from the delivery of high arable weed diversity on their fields were determined. As the cost-effectiveness of a conservation auction increases if payments compensate just farmers' opportunity costs of contract compliance (Ferraro, 2008), it was explicitly tested whether bid prices of participating farmers reflected their actual opportunity costs. It was hypothesised that (i) weed species richness is higher on PES compared to conventionally managed fields and (ii) that farmers' bid prices are highly related to the actual opportunity costs for the provision of the environmental service.

\section{References}

AEBISCHER NJ. (1991). Twenty years of monitoring invertebrates and weeds in cereal fields in Sussex. L. G. Firbank, N. Carter, J. F. Darbyshire \& G. R. Potts (Eds.), The Ecology of Temperate Cereal Fields (pp. 305-331). London, UK: Blackwell Scientific Publications.

ALBRECHT H (2003) Suitability of arable weeds as indicator organisms to evaluate species conservation effects of management in agricultural ecosystems. Agriculture, Ecosystems and Environment 98, 201-211.

AltiERI MA (1999) The ecological role of biodiversity in agroecosystems. Agriculture, Ecosystems and Environment 74, 19-31.

Balmford A, Bruner A, Cooper P, Costanza R, Farber S, Green RE, Jenkins M, JefFeriss P, Jessamy V, Madden J, Munro K, Myers N, Naeem S, PaAvola J, 
Rayment M, Rosendo S, Roughgarden J, Trumper K \& Turner K (2002) Economic Reasons for Conserving Wild Nature. Science 297, 950-953.

BÀrberi P, SILVESTRI N \& BONARI E (1997) Weed communities of winter wheat as influenced by input level and rotation. Weed Research 37, 301-313.

Bengtsson J, Ahnstrom J \& Weibull AC (2005) The effects of organic agriculture on biodiversity and abundance: a meta analysis. Journal of Applied Ecology 42, 261269.

BoAtMAn ND, BEnCE SL \& JARVIS P (1999) Management and costs of conservation headlands on heavy soil. Aspects of Applied Biology 54, 147-154.

Boatman ND, Hart A, Clook M, Brown VK, Holland JM \& LutMan PJW (2003) A risk assessment framework for determining the effects of pesticides on farmland biodiversity. Proceedings of the BCPC International Congress - Crop Science and Technology, 239-244.

CARdina J, Herms CP \& Doohan DJ (2002) Crop rotation and tillage system effects on weed seedbanks. Weed Science 50, 448-460.

Clements DR, Weise SF \& Swanton CJ (1994) Integrated weed management and weed species diversity. Phytoprotection 75, 1-18.

CONNOR JD, WARD JR \& BRYAN B (2008) Exploring the cost effectiveness of land conservation auctions and payment policies. The Australian Journal of Agricultural and Resource Economics 51, 303-319.

Doucet C, Weaver SE, Hamill AS \& Zhang J (1999) Separating the effects of crop rotation from weed management on weed density and diversity. Weed Science 47, 729-735.

FERRARO PJ (2001) Global habitat protection: Limitations of development interventions and a role for conservation performance payments. Conservation Biology 15, 9901000.

FERRARO PJ (2008) Asymmetric information and contract design for payments for environmental services. Ecological Economics 65, 810-821.

FERRARO PJ \& KISS A (2002) Direct payments to conserve biodiversity. Science 298, 1718-1719.

FrANKE AC, LOTZ LAP, VAN DER BURG WJ \& VAN OVERBEEK L (2009) The role of arable weed seeds for agroecosystem functioning. Weed Research 49, 131-141.

GABRIEL D \& TSCHARNTKE T (2006) Insect pollinated plants benefit from organic farming. Agriculture, Ecosystems \& Environment 118, 43-48. 
HÅKANSSON S (2003) Weeds and weed management on arable land: an ecological approach. Oxon, UK: CABI Publishing.

HALD AB (1999) The impact of changing the season in which cereals are sown on the diversity of the weed flora in rotational fields in Denmark. Journal of Applied Ecology 36, 24-32.

HALD AB (1999) Weed vegetation (wild flora) of long established organic versus conventional cereal fields in Denmark. Annals of Applied Biology 134, 307-314.

Hawes C, Haughton aj, Osborne Jl, Roy DB, Clark SJ, Perry Jn, Rothery P, Bohan DA, Brooks DR, Champion GT, Dewar AM, Heard MS, Woiwod IP, Daniels RE, Young MW, Parish AM, Scott RJ, Firbank LG \& Squire GR (2003) Responses of plants and invertebrate trophic groups to contrasting herbicide regimes in the Farm Scale Evaluations of genetically modified herbicide-tolerant crops. Philosophical Transactions of the Royal Society B 358, 1899-1913.

Hole DG, Perkins AJ, Wilson JD, Alexander IH, Grice F \& Evans AD (2005) Does organic farming benefit biodiversity? Biological Conservation 122, 113-130.

HYVÖNEN T \& HuUSElA-VEISTOla E (2008) Arable weeds as indicators of agricultural intensities - A case study from Finland. Biological Conservation 141, 2857-2864.

HYVÖNEN T \& SALONEN J (2002) Weed species diversity and community composition in cropping practices at two intensity levels - a six-year experiment. Plant Ecology 159, 73-81.

JONES NE \& SMITH BM (2007) Effects of selective herbicide treatments, row width and spring cultivation on weed and arthropod communities in winter wheat. Aspects of Applied Biology 81, 39-46.

Knop E, Kleijn D, Herzog F \& Schmid B (2006) Effectiveness of the Swiss agrienvironment scheme in promoting biodiversity. Ecology 43, 120-127.

LÉGÈRE A \& SAMSON N (2004) Tillage and weed management effects on weeds in barleyred clover croppping systems. Weed Science 52, 881-885.

LIEBMAN M (2001) Weed Management: a need for ecological approaches. M. Liebman, C. L. Mohler \& C. P. Staver (Eds.), Ecological Management of Agricultural Weeds (pp. 532 p). Cambridge, UK: Cambridge University Press.

LIEBMAN M \& DYCK E (1993) Crop rotation and intercropping strategies for weed management. Ecological Applications 3, 92-122. 
LUTMAN PJW (2005) Sustainable weed management: development of techniques to balance biodiversity benefits with retention of yield. Research Project Final Report, UK Government.

Marshall EJP, Brown VK, BoAtman ND, LutMan PJW, SQuire GR \& WARD LK (2003) The role of weeds in supporting biological diversity within crop fields. Weed Research 43, 77-89.

Menalled FD, Gross KL \& Hammond M (2001) Weed aboveground and seedbank community responses to agricultural management systems. Ecological Applications 11, 1586-1601.

Naidoo R, Balmford A, Ferraro PJ, Polasky S, Ricketts TH \& Rouget M (2006) Integrating economic costs into conservation planning. TRENDS in Ecology and Evolution 21, 681-687.

Nentwig W, Frank T \& Lethmayer C (1998) Sown weed strips: Artificial ecological compensation areas as an important tool in conservation biological control. P. Barbosa (Ed.), Conservation biological control. San Diego USA: Academic Press.

NORRIS RF \& KOGAN M (2005) Ecology of interactions between weeds and arthropds. Annual Review of Entomology 50, 479-503.

PotTs GR, EwAld JA \& AEBISCHER NJ (2010) Long-term changes in the flora of the cereal ecosystem on the Sussex Downs, England, focusing on the years 1968-2005. Journal of Applied Ecology 47, 215-226.

RAsmussen IA, AsKegaARD M, Olesen JE \& Kristensen K (2006) Effects on weeds of management in newly converted organic crop rotations in Denmark. Agriculture, Ecosystems \& Environment 113, 184-195.

RoBINSON RA \& WILLIAM JS (2002) Post-war changes in arable farming and biodiversity in Great Britain. Journal of Applied Ecology 39, 157-176.

Roschewitz I, Gabriel D, Tscharntke T \& Thies C (2005) The effects of landscape complexity on arable weed species diversity in organic and conventional farming. Journal of Applied Ecology 42, 873-882.

SCHELLHORN NA \& SORK VL (1997) The impact of weed diversity on insect populations dynamics and crop yield in collards, Brassica oleracea (Brassicaceae). Oecologia 111, 233-240.

SCHILIZZI S \& LATACZ-LOHMANN U (2007) Assessing the performance of conservation auctions: An experimental Study. Land Economics 83, 497-515. 
Smith BM, Holland JM, Jones NE, Moreby S, Morris AJ \& Southway SE (2009) Enhancing invertebrate food resources for skylarks in cereal ecosystems: how useful are in-crop agri-environment scheme management options? Journal of Applied Ecology 46, 692-702.

SMITH RG \& GROSS KL (2007) Assembly of weed communities along a crop diversity gradient. Journal of Applied Ecology 44, 1046-1056.

SOTHERTON NW, RANDS MRW \& MOREBy SJ (1985) Comparison of herbicide treated and untreated headlands for the survival of game and wildlife. British Crop Protection Conference: weeds, Farnham, UK.

STORKEY J (2006) A functional group approach to the management of UK arable weeds to support biological diversity. Weed Research 46, 513-522.

StORKey J \& Westbury DB (2007) Managing arable weeds for biodiversity. Pest Management Science 63, 517-523.

SUTCLIFFE OL \& KAY QON (2000) Changes in the arable flora of central southern England since the 1960s. Biological Conservation 93, 1-8.

TEN Brink P, BerghöFER A, Schröter-SchlaAck C, Sukhdev P, VAKrou A, White S \& WiTTMER H (2009) TEEB-The Economics of Ecosystems and Biodiversity for National and International Policy Makers. Summary: Responding to the Value of Nature.

WEIL RR (1982) Maize-weed competition and soil erosion in unweeded maize. Tropical Agriculture 59, 207-213.

Wunder S, Engel S \& PAgiola S (2008) Taking stock: A comparative analysis of payments for environmental services programs in developed and developing countries. Ecological Economics 65, 834-852. 


\section{CHAPTER}

2

An experimental on-farm approach to investigate the impact of

diversified crop rotations on weed species richness and composition in winter wheat

Lena Ulber, Horst-Henning Steinmann, Sebastian Klimek \& Johannes Isselstein 


\section{Summary}

Weed species diversity may benefit from organic farming due to enhanced temporal diversification of crop species in a rotation and omission of herbicide applications. In intensively managed conventional systems however, little evidence exists as to what extent diversified crop rotations contribute to higher weed species richness. Using an on-farm approach, the effect of crop rotation (organic, conventional diverse and conventional simple crop rotations) and weed control (with vs. without) on weed species richness, cover and community composition, and on crop biomass, was analysed in 24 winter wheat fields. Weed species with beneficial functions for invertebrates and birds were analysed separately. Weed species richness was higher in the organic crop rotation but did not differ between conventional diverse and conventional simple crop rotations. Weed control treatment reduced species richness in both conventional rotations but not in the organic one. Redundancy analyses revealed that crop rotation intensity accounted for a large part of the explained variation in weed species composition. Results from the study indicate that the maintenance of weed species richness and conservation of species with important ecological functions requires not only temporal diversification of crop species in the rotation but also an adjustment of weed control strategies.

Keywords: arable weeds, biodiversity, cropping system, conventional farming, herbicide use, organic farming, weed control 


\section{Introduction}

In recent decades, weed species diversity in agricultural landscapes has declined due to intensification of farming practices accompanied by intensive input of broad-spectrum herbicides, increased nitrogen fertilisation rates and simplification of crop rotations (Hyvönen \& Salonen, 2002; Robinson \& William, 2002). There is considerable evidence that arable weeds play an important role in providing resource and habitat to higher trophic levels including farmland birds (Altieri, 1999; Storkey \& Westbury, 2007). Weed species, however, differ in their biodiversity value (sensu Storkey, 2006) (importance as resources for invertebrates and seed-eating birds), as well as in their impediment to crop production (Boatman et al., 2003; Storkey \& Westbury, 2007).

Numerous studies quantifying the impact of management systems on biodiversity have compared conventional and organic farming at different taxa levels and found organic farming to promote higher species richness of the above ground vegetation (Hald, 1999a; Hole et al., 2005; Roschewitz et al., 2005) and the soil seed bank (Menalled et al., 2001). Conventional farming systems also vary in their relative influence on weed species diversity and community composition according to the intensity of external inputs used as well as type of tillage systems and crop rotations. It is known that diversified crop rotations may reduce the abundance of dominant weed species (Liebman \& Dyck, 1993) and enhance crop productivity in cropping systems (Smith et al., 2008). Despite these beneficial effects, the majority of current temperate conventional cropping systems are characterized by monocultures, or simple rotations with a limited number of crops (Jolliffe, 1997). It has therefore been questioned whether an enhanced temporal diversification of crop species in a rotation would promote an increase in weed species diversity (Liebman \& Dyck, 1993; Smith \& Gross, 2006). Although the relationship between number of crop species in the rotation and weed species richness has already been investigated (Liebman \& Dyck, 1993; Bàrberi et al., 1997; Doucet et al., 1999; Squire et al., 2000; Cardina et al., 2002; Smith \& Gross, 2007), the extent to which diversified crop rotations contribute to higher weed species richness in intensively managed conventional systems has not been extensively studied.

In addition to the influence of crop rotation, the application of synthetic broad-spectrum herbicides in conventional cropping systems may exert important effects on weed species richness. While a long-term application of herbicides alters both the structure of above ground weed communities and soil seed bank composition (Bàrberi et al., 1997), the short- 
term influence of herbicide application predominantly impoverishes the above ground weed species richness and abundance (Aebischer, 1991; Hald, 1999b). A comparison of the above ground weed species richness of herbicide-treated conventional fields paired with fields from organic farming systems might therefore be biased towards very low species abundances in conventional systems, as it ignores the plant diversity present as seeds in soil seed banks (Thompson \& Grime, 1979).

In this study, we examined the effect of crop rotation intensity and weed control treatment on weed species richness, cover and composition in winter wheat (Triticum aestivum L.). In addition, we investigated how weed species of high biodiversity value but low competitive ability responded to both experimental factors. Using an on-farm approach, we defined three levels of crop rotation intensity representing organic, conventional diverse and conventional simple crop rotations. The impact of weed control treatment (with vs. without) was assessed by establishing plots without weed control. To account for the negative impact of weed abundance on crop yields, we analysed wheat grain biomass under the influence of weed control treatment vs. no weed control treatment. Generally, we expected weed species richness to be higher under organic compared to conventional farming practice. The experimental factors were therefore designed specifically to test the following hypotheses: (i) conventional diverse crop rotation would show higher weed species richness compared to conventional simple crop rotation; (ii) weed control would reduce weed species richness independently of level of crop rotation intensity.

\section{Material and Methods}

\section{Study Sites and Experimental Design}

The study was conducted in 2007 in the administrative district of Northeim in Lower Saxony, Germany. Arable land comprises about $37 \%$ of the district's area $\left(1267 \mathrm{~km}^{2}\right)$. Conventional crop rotations in the region are often reduced to two crop species (winter wheat and winter oilseed rape). Spring cereals, which have been found to contribute to higher weed species richness in comparison to winter cereals (Andreasen et al., 1996; Hald, 1999b), are less frequently integrated into conventional crop rotations due to lower gross margins.

Twenty-four fields of winter wheat belonging to 20 farmers were surveyed. We selected fields from three crop rotation intensities (CRI): (i) organic farming system: organic crop rotation with 3-5 crop species including legumes $(\mathrm{O})$; (ii) conventional farming system: 
simple crop rotation with $\leq 3$ autumn-sown crop species including exclusively winter cereals and winter oilseed rape (CS); (iii) conventional farming system: diverse crop rotation with 3-5 crop species, including autumn-sown crops (winter cereals) and at least one spring crop (spring cereals, maize, legumes) and/or periods of fallow (Table 2.1). For determination of crop rotation type, information on cropping history of the fields for the last 10 years was provided by the farmers. All organic farmers cultivated winter wheat according to European Union (EU) regulation 2092/91/EEC. The earliest conversion date for organic farms was 1980 and the latest 2002, with an average of 11.8 years postconversion. In conventional crop rotations, the defined crop rotations had been in place for at least six years.

All 24 fields were grouped into eight triplets each consisting of three fields belonging to one of the three types of crop rotation intensity (Fig. 2.1). Fields in each triplet were chosen according to geographical proximity to allow for similar environmental conditions and landscape context. Minimum distance between triplets was $4 \mathrm{~km}$, maximum distance was $30 \mathrm{~km}$ and mean distance $19.9 \pm 7.3 \mathrm{~km}$ (mean $\pm \mathrm{SD}$ ). Within the triplets, fields had an average distance of $1.1 \pm 0.6 \mathrm{~km}$. The mean size of the study fields was $4.3 \pm 2.8$ ha and was not related to crop rotation intensity (ANOVA, $F=1.57, P=0.22$ ).

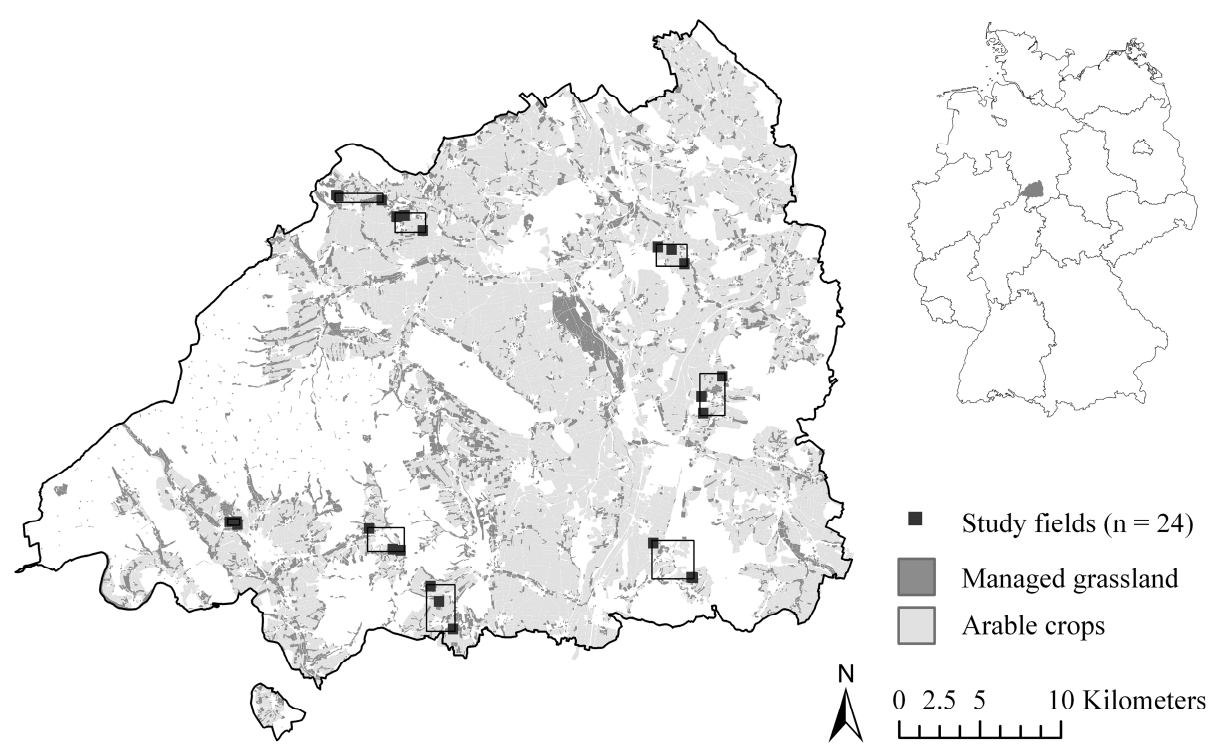

Fig. 2.1 Location of the 24 study fields of winter wheat in the district of Northeim (Lower Saxony, Germany). The eight triplets consisting of three fields from different crop rotation intensities are each shown in rectangles. 
To facilitate comparisons based on number of active ingredients used, herbicide inputs comprising both dose rates and area treated were converted into a standardised treatment index according to Sattler et al. (2006). In our experimental design, mean nitrogen fertilisation rates and herbicide inputs did not differ significantly between conventional diverse and conventional simple crop rotation (Table 2.1) (paired $t$-test, $P>0.13$ and $P>0.79$, respectively).

In the centre of each field, two paired plots (each $10 \mathrm{~m} \times 10 \mathrm{~m}$ ) were established. To separate the effect of crop rotation intensity from the effect of weed control treatment, one of the sub-plots received no weed control treatment. In these plots, nozzles of the field crop sprayer were closed during herbicide application in conventional fields and no mechanical weed control was conducted in organic fields. Herbicides and a single weed harrowing were applied according to farmers' regular weed control in the adjacent sub-plots of conventional and organic farms, respectively. The experimental design followed a splitplot-design with eight replicates and crop rotation intensity (CRI) as main factor and weed control (WCT) as sub-factor.

Ten randomly taken soil samples from the top layer $(0-30 \mathrm{~cm})$ of each field were analysed. Soil nutrient properties $(\mathrm{pH}$, potassium, phosphorus and magnesium content) and $\mathrm{N}$ fertilisation rates within each level of crop rotation intensity were not significantly correlated with our dependent variables (all $P>0.05$ ).

\section{Winter wheat grain sampling}

Grain biomass of winter wheat was sampled in July at maturity from four $0.5 \mathrm{~m}$ x $0.5 \mathrm{~m}$ quadrats in each plot. Winter wheat ears were dried at $105^{\circ} \mathrm{C}$ for $24 \mathrm{~h}$, mechanically threshed and the grains weighed. 
Table 2.1 Crop management practices and size of winter wheat fields (2006-2007 season) of eight organic, conventional diverse and conventional simple crop rotation intensities $(n=24)$. Means \pm SEM, minima and maxima are given .

\begin{tabular}{|c|c|c|c|}
\hline & Organic & Conventional diverse & Conventional simple \\
\hline Use of herbicides & - & All fields & All fields \\
\hline Active ingredients used & - & $\begin{array}{l}\text { amidosulfuron, } \\
\text { bifenox, carfentrazone, } \\
\text { iodosulfuron, iso- } \\
\text { proturon, fenoxaprop- } \\
\text { P, florasulam, } \\
\text { fluroxypyr, ioxynil, } \\
\text { mecoprop-P, } \\
\text { mesosulfuron, met- } \\
\text { sulfuron, pinoxaden, } \\
\text { propoxycarbazone }\end{array}$ & $\begin{array}{l}\text { amidosulfuron, } \\
\text { bifenox, carfentrazone, } \\
\text { iodosulfuron, } \\
\text { fenoxaprop-P, } \\
\text { florasulam, ioxynil, } \\
\text { mecoprop-P, meso- } \\
\text { sulfuron, metsulfuron, } \\
\text { pinoxaden, propoxy- } \\
\text { carbazone }\end{array}$ \\
\hline $\begin{array}{l}\text { Mechanical weed } \\
\text { control }\end{array}$ & Seven fields & - & - \\
\hline Use of plough tillage & Seven fields & Five fields & Seven fields \\
\hline Previous crop & $\begin{array}{l}\text { Clover-grass- } \\
\text { mixture }\end{array}$ & Maize, spring cereals & $\begin{array}{l}\text { Winter wheat, oilseed } \\
\text { rape }\end{array}$ \\
\hline Crop types in rotation & $\begin{array}{l}\text { Winter cereals, } \\
\text { spring cereals, } \\
\text { oilseed rape, } \\
\text { legumes potatoes, } \\
\text { clover-grass-mixture }\end{array}$ & $\begin{array}{l}\text { Winter cereals, spring } \\
\text { barley, oats, oilseed } \\
\text { rape, lupins, sugar } \\
\text { beet, maize, fallow }\end{array}$ & $\begin{array}{l}\text { Winter wheat, winter } \\
\text { barley, winter rye, } \\
\text { oilseed rape }\end{array}$ \\
\hline $\begin{array}{l}\text { Legumes in crop } \\
\text { rotation }\end{array}$ & Seven fields & One field & - \\
\hline $\begin{array}{l}\text { No of crops in rotation } \\
\text { (over the last } 10 \text { years) }\end{array}$ & $4.0 \pm 0.5(3-5)$ & $3.9 \pm 0.7(3-5)$ & $3.0 \pm 0.0$ \\
\hline $\begin{array}{l}\text { Standardised treatment } \\
\text { index* }\end{array}$ & & $1.76 \pm 0.42(1.3-2.5)$ & $1.7 \pm 0.5(1.8-2.0)$ \\
\hline $\begin{array}{l}\text { Mineral N-fertilisation } \\
\left(\mathrm{kg} \mathrm{ha}^{-1}\right)\end{array}$ & - & $197 \pm 24.3(169-241)$ & $170 \pm 40.4(80-212)$ \\
\hline $\begin{array}{l}\text { Organic N-fertilisation } \\
\left(\mathrm{kg} \mathrm{ha}^{-1}\right)\end{array}$ & $5.4 \pm 9.4(0-22)$ & $6.9 \pm 19.4(0-55)$ & $2.8 \pm 8.0(0-23)$ \\
\hline Field size (ha) & $2.7 \pm 2.1(0.5-4.4)$ & $4.8 \pm 2.6(2.1-10.6)$ & $4.4 \pm 2.8(1.1-7.2)$ \\
\hline
\end{tabular}

*The treatment index takes the number of herbicide applications, dose rates and treated area into account (Sattler et al., 2006) 
Vegetation sampling

In both plots of each field, weed species were surveyed in June (after weed control had been completed) and percentage cover of each species was estimated within the whole $100 \mathrm{~m}^{2}$ plot according to a modified Londo scale (Londo, 1976) which records weed cover in steps from 1-3\%, 3-5\% and then in 10\% steps from 5 to $95 \%$ and a final step from 95-100\%. According to Dierschke (1994), weed cover values < $1 \%$ were further classified according to abundance of plant species (single, few and numerous individuals). Nomenclature of plant species followed that of Haeupler and Muer (2000). Tree seedlings and volunteer crop species were not considered. In addition, we classified a subset of 10 weed species with high biodiversity value and low to moderate competitive ability towards the crop (Table 2.2) adapted from Marshall et al. (2003) and Storkey (2006). This biodiversity value indicates weed species importance in providing resource for seed-eating birds and invertebrates and its competitive ability towards the crop.

\section{Statistical analysis}

Linear mixed-effects models were fitted in R (R Development Core Team, 2007) which, according to the split-plot design, incorporated the following error structure (number of levels indicated in parentheses): "triplet" (8)/"crop rotation intensity" (3)/"weed control treatment" (2). As the study was characterised by a balanced and orthogonal design, maximum likelihood (ML) was used within the linear mixed-effects models. Triplet was included as a random block factor to account for environmental heterogeneity between triplets. The response variables tested were species richness, species richness of species with biodiversity value, total percentage weed cover (arcsine square-root transformed) and winter wheat grain biomass $\left(\mathrm{g} \mathrm{m}^{-2}\right)$. Model simplification of the maximal model was done by sequentially deleting non-significant terms (starting with highest-order interactions) and by comparing each model with its predecessor using Akaike information criterion (AIC; Burnham \& Anderson, 1998) until minimal adequate models were retrieved. The appropriateness of the model was checked by plotting standardised residuals against fitted values. Statistically significant effects derived from the model with best fit were further investigated using ANOVA following the error structure of the linear mixed-effects models and Tukey HSD post-hoc tests $(P<0.05)$ on data averaged over triplets.

To distinguish the relative contributions of the experimental factors in explaining weed species composition, we used redundancy analyses (RDA) on arcsine square-root 
transformed weed cover data. We opted for RDA rather than canonical correspondence analysis (CCA) as previous detrended correspondence analysis (DCA) indicated the adequacy of a linear based ordination technique. According to the linear mixed-effect models, we considered the experimental factors crop rotation intensity (CRI), weed control treatment (WCT) and triplet (TRI). Using a series of (partial) RDA analyses, we determined the amount of variation that was either explained by the full model or by each experimental factor separately. When testing the unique effects of CRI and WCT, the other factor was used as a covariable with triplet included as a blocking factor. For analysis of the unique effect of TRI, the covariables were CRI and WCT. The total variation explained by the full model was equal to the sum of variation explained by each single factor separately, i.e. the factors were not correlated with each other and did not share any proportion of explained variation. The statistical significance of the RDA models was evaluated by Monte Carlo permutation tests (1000 random permutations). All the analyses were carried out in CANOCO version 4.5 (ter Braak \& Smilauer, 2002).

\section{Results}

Seventy-five weed species were encountered in the survey (Table 2.2). The accumulated number of observed species pooled over fields was highest in the organic crop rotation with 59 species. Within the conventional crop rotations, 38 species were observed in the diverse crop rotation and 31 species in the simple crop rotation, respectively. Out of the 10 species with biodiversity value found across all fields, 10 were observed in the organic fields and eight and seven in the diverse crop rotation and simple crop rotation, respectively. 
Table 2.2 Life cycle and frequency of occurrence (number of plots in which each species was detected), and biodiversity value (*) of weed species across eight winter wheat fields for each crop rotation intensity. NT, without weed control treatment; T, with weed control treatment. A, annual; $\mathrm{B}$, biennial; P, perennial.

\begin{tabular}{|c|c|c|c|c|}
\hline Species & $\begin{array}{l}\text { Life } \\
\text { cycle }^{\dagger}\end{array}$ & Organic & $\begin{array}{l}\text { Conventional } \\
\text { diverse }\end{array}$ & $\begin{array}{l}\text { Conventional } \\
\text { simple }\end{array}$ \\
\hline
\end{tabular}

\section{Dicotyledonous species}

Anchusa arvensis (L.) M. BIEB.

Anthemis cotula L.

Aphanes arvensis L.

Arabidopsis thaliana (L.) HEYNH.

\begin{tabular}{llllll} 
NT & T & NT & T & NT & T \\
\hline
\end{tabular}

Capsella bursa-pastoris (L.) MED.*

Centaurea cyanus L.

Cerastium glomeratum THUILL.

Cerastium holosteoides FR.

Chenopodium album L. *

Cirsium arvense (L.) SCOP.

Crepis biennis L.

Epilobium obscurum SCHREB.

Epilobium tetragonum L.

Equisetum arvense L.

Euphorbia helioscopia L.

Fallopia convolvulus (L.) Á.LOEVE*

Fumaria officinalis L.

Galeopsis tetrahit L.

Galium aparine L.

Geranium dissectum L.

Geranium molle L.

Lamium purpureum L. *

Lapsana communis L.

Matricaria recutita L.

Medicago sativa L.

Myosotis arvensis (L.) HILL

Papaver argemone L.

Papaver dubium L.

Papaver rhoeas L.

\begin{tabular}{|c|c|c|c|c|c|}
\hline A & 1 & 1 & 0 & 0 & 0 \\
\hline A & 1 & 1 & 0 & 0 & 0 \\
\hline A & 7 & 7 & 7 & 5 & 7 \\
\hline A & 3 & 3 & 0 & 0 & 0 \\
\hline A & 2 & 2 & 3 & 0 & 3 \\
\hline A & 1 & 1 & 0 & 0 & 0 \\
\hline A & 1 & 1 & 1 & 0 & 0 \\
\hline $\mathrm{P}$ & 0 & 1 & 1 & 0 & 0 \\
\hline A & 2 & 2 & 1 & 0 & 1 \\
\hline $\mathrm{P}$ & 5 & 4 & 2 & 1 & 1 \\
\hline B & 0 & 0 & 0 & 0 & 1 \\
\hline $\mathrm{P}$ & 0 & 0 & 1 & 0 & 0 \\
\hline $\mathrm{P}$ & 0 & 0 & 3 & 1 & 1 \\
\hline $\mathrm{P}$ & 3 & 3 & 1 & 1 & 0 \\
\hline A & 0 & 1 & 0 & 0 & 0 \\
\hline A & 5 & 4 & 3 & 2 & 0 \\
\hline A & 0 & 0 & 2 & 1 & 0 \\
\hline A & 0 & 1 & 0 & 0 & 0 \\
\hline A & 6 & 5 & 7 & 6 & 6 \\
\hline $\mathrm{A} / \mathrm{B}$ & 1 & 1 & 0 & 0 & 0 \\
\hline $\mathrm{A} / \mathrm{B}$ & 0 & 0 & 1 & 0 & 0 \\
\hline $\mathrm{A} / \mathrm{B}$ & 2 & 3 & 3 & 2 & 2 \\
\hline A & 2 & 2 & 0 & 0 & 0 \\
\hline A & 8 & 7 & 5 & 0 & 3 \\
\hline $\mathrm{P}$ & 1 & 1 & 0 & 0 & 0 \\
\hline A & 7 & 7 & 6 & 3 & 6 \\
\hline A & 1 & 1 & 0 & 0 & 0 \\
\hline A & 2 & 1 & 2 & 0 & 0 \\
\hline A & 3 & 3 & 3 & 1 & 6 \\
\hline
\end{tabular}




\begin{tabular}{|c|c|c|c|c|c|c|c|}
\hline \multirow[t]{2}{*}{ Species } & \multirow[t]{2}{*}{$\begin{array}{l}\text { Life } \\
\text { cycle } \dagger\end{array}$} & \multicolumn{2}{|c|}{ Organic } & \multicolumn{2}{|c|}{$\begin{array}{l}\text { Conventional } \\
\text { diverse }\end{array}$} & \multicolumn{2}{|c|}{$\begin{array}{l}\text { Conventional } \\
\text { simple }\end{array}$} \\
\hline & & NT & $\mathrm{T}$ & NT & $\mathrm{T}$ & NT & $\mathrm{T}$ \\
\hline Persicaria maculosa GRAY * & $\mathrm{A}$ & 0 & 1 & 0 & 0 & 0 & 0 \\
\hline $\begin{array}{l}\text { Plantago major spp. intermedia } \\
\text { (GILIB.) LANGE }\end{array}$ & $\mathrm{P}$ & 1 & 0 & 0 & 0 & 0 & 0 \\
\hline Plantago major spp. major L. & $\mathrm{P}$ & 0 & 1 & 0 & 0 & 0 & 0 \\
\hline Polygonum aviculare L. * & A & 4 & 4 & 3 & 1 & 3 & 2 \\
\hline Ranunculus acris L. & $\mathrm{P}$ & 0 & 0 & 0 & 0 & 0 & 0 \\
\hline Ranunculus repens L. & $\mathrm{P}$ & 1 & 0 & 0 & 1 & 0 & 0 \\
\hline Raphanus sativus L. & A & 0 & 1 & 0 & 0 & 0 & 0 \\
\hline Rumex acetosa L. & $\mathrm{P}$ & 0 & 0 & 1 & 0 & 0 & 0 \\
\hline Rumex crispus L. & $\mathrm{P}$ & 5 & 2 & 0 & 0 & 1 & 0 \\
\hline Rumex obtusifolius L. & $\mathrm{P}$ & 0 & 0 & 1 & 0 & 0 & 0 \\
\hline Scleranthus annuus L. & A & 2 & 2 & 0 & 0 & 0 & 0 \\
\hline Sinapis arvensis L. * & A & 4 & 2 & 0 & 0 & 0 & 0 \\
\hline Sonchus arvensis L. & $\mathrm{P}$ & 1 & 2 & 1 & 0 & 0 & 0 \\
\hline Sonchus asper (L.) HILL & A & 1 & 2 & 0 & 0 & 1 & 2 \\
\hline Sinapis alba L. & A & 0 & 0 & 0 & 0 & 0 & 0 \\
\hline Stachys palustris L. & $\mathrm{P}$ & 1 & 1 & 0 & 0 & 0 & 0 \\
\hline Stellaria media (L.) VILL. * & A & 5 & 4 & 3 & 2 & 4 & 0 \\
\hline Taraxacum officinale agg. WEBER & $\mathrm{P}$ & 3 & 4 & 0 & 0 & 0 & 0 \\
\hline Thlaspi arvense L. & A & 2 & 3 & 0 & 0 & 1 & 0 \\
\hline Trifolium pratense L. & $\mathrm{P}$ & 2 & 1 & 0 & 0 & 0 & 0 \\
\hline Trifolium repens L. & $\mathrm{P}$ & 1 & 0 & 1 & 1 & 0 & 0 \\
\hline
\end{tabular}

Tripleurospermum perforatum

(MÉRAT) LAINZ *

Valerianella dentata (L.) POLLICH

Valerianella locusta (L.) LATERR.

Veronica arvensis L.

Veronica hederifolia L.

Veronica opaca Fr.

Veronica persica POIRET

$\begin{array}{lllllll}\text { A } & 2 & 2 & 1 & 0 & 0 & 0\end{array}$

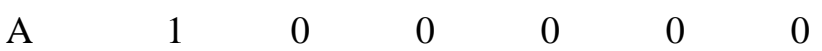

$\begin{array}{lllllll}\text { A } & 1 & 1 & 0 & 0 & 0 & 0\end{array}$

$\begin{array}{lllllll}\text { A } & 3 & 2 & 2 & 2 & 2 & 2\end{array}$

$\begin{array}{lllllll}\text { A } & 3 & 3 & 4 & 5 & 4 & 4\end{array}$

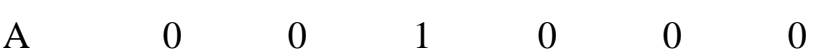

$\begin{array}{lllllll}\text { A } & 3 & 3 & 4 & 3 & 3 & 4\end{array}$

Veronica polita FR.

Vicia hirsuta (L.) GRAY

Vicia sativa (L.)

Vicia tetrasperma (L.) SCHREB.

$\begin{array}{lllllll}\text { A } & 1 & 0 & 0 & 0 & 1 & 0\end{array}$

$\begin{array}{lllllll}\text { A } & 6 & 6 & 0 & 0 & 2 & 0\end{array}$

$\begin{array}{lllllll}\text { A } & 4 & 4 & 0 & 0 & 0 & 0\end{array}$

Vicia villosa ROTH

$\begin{array}{lllllll}\mathrm{A} & 2 & 2 & 0 & 0 & 0 & 0\end{array}$

$\begin{array}{lllllll}\text { A } & 1 & 1 & 0 & 0 & 0 & 0\end{array}$




\begin{tabular}{lccccccc}
\hline Species & $\begin{array}{l}\text { Life } \\
\text { cycle }\end{array}$ & Organic & \multicolumn{2}{c}{$\begin{array}{l}\text { Conventional } \\
\text { diverse }\end{array}$} & \multicolumn{3}{c}{$\begin{array}{l}\text { Conventional } \\
\text { simple }\end{array}$} \\
& & NT & T & NT & T & NT & T \\
\hline Viola arvensis MURRAY & $\mathrm{A}$ & 6 & 8 & 6 & 5 & 8 & 7 \\
Grass species & & & & & & & \\
Alopecurus myosuroides HUDS. & $\mathrm{A}$ & 5 & 4 & 6 & 3 & 5 & 2 \\
Apera spica-venti (L.) P. BEAUV. & $\mathrm{A}$ & 5 & 4 & 4 & 1 & 7 & 3 \\
Arrhenatherum elatius (L.) & & & & & & & \\
P. BEAUV. EX J.\& C. PRESL & $\mathrm{P}$ & 0 & 1 & 0 & 0 & 0 & 0 \\
Avena fatua L. & $\mathrm{A}$ & 1 & 1 & 1 & 0 & 0 & 0 \\
Bromus sterilis L. & $\mathrm{A} / \mathrm{B}$ & 0 & 0 & 0 & 0 & 0 & 1 \\
Elymus repens (L.) GoULD & $\mathrm{P}$ & 2 & 2 & 1 & 1 & 1 & 1 \\
Holcus lanatus L. & $\mathrm{P}$ & 0 & 0 & 1 & 1 & 0 & 0 \\
Lolium multiflorum LAM. & $\mathrm{A}$ & 1 & 1 & 1 & 0 & 0 & 0 \\
Lolium perenne L. & $\mathrm{P}$ & 1 & 1 & 0 & 0 & 0 & 0 \\
Phleum pratense L. & $\mathrm{P}$ & 1 & 0 & 0 & 0 & 0 & 0 \\
Poa annua L. * & $\mathrm{A}$ & 4 & 4 & 2 & 1 & 3 & 1 \\
Poa trivialis L. & $\mathrm{P}$ & 0 & 0 & 3 & 1 & 3 & 1 \\
\hline
\end{tabular}

* biodiversity value after Marshall et al. (2003) and Storkey (2006)

${ }^{\dagger} \operatorname{Hanf}(1999)$

\section{Weed species richness, weed cover and grain biomass of winter wheat}

At plot level, mean weed species richness was influenced by crop rotation intensity (CRI), weed control treatment (WCT) and the interaction between these two factors (Table 2.3). No differences in species richness between conventional diverse (CD) and conventional simple (CS) rotation were detected for both plots with (T) and without (NT) weed control treatment (Fig. 2.2 a). The impact of weed control treatment on species richness was significant in both conventional crop rotations but not in plots of the organic rotation (CRI x WCT, P < 0.05). 
Table 2.3 Effects of crop rotation intensity (CRI: O, organic crop rotation; CD, diverse conventional crop rotation; CS, simple conventional crop rotation) and weed control treatment (WCT: NT, without weed control treatment; T, with weed control treatment) on species richness, richness of species of high biodiversity value, weed cover, and grain biomass of winter wheat in 24 winter wheat fields (linear mixed-effects models). Non significant interaction terms were excluded during model simplification. Significance levels are $* * * P<0.001 ; * * P<0.01 ; * P<0.05$; NS, not significant. Direction of effect based on post-hoc test (Tukey HSD).

\begin{tabular}{|c|c|c|c|c|c|}
\hline & Source & df & MS & $F$ & $\begin{array}{l}\text { Direction of } \\
\text { effect }\end{array}$ \\
\hline \multirow[t]{4}{*}{ Species richness } & CRI & 2 & 496.33 & $9.23 * *$ & $\mathrm{O}>\mathrm{CD}=\mathrm{CS}$ \\
\hline & WCT & 1 & 165.02 & $20.96 * * *$ & $\mathrm{NT}>\mathrm{T}$ \\
\hline & $\mathrm{CRI} \times \mathrm{WCT}$ & 2 & 30.08 & 3.82* & \\
\hline & Residuals & 42 & 30.81 & & \\
\hline \multirow[t]{3}{*}{ Species richness biodiversity value } & CRI & 2 & 21.33 & $3.62 \mathrm{NS}$ & \\
\hline & WCT & 1 & 8.33 & $8.45 * *$ & $\mathrm{NT}>\mathrm{T}$ \\
\hline & Residuals & 44 & 4.06 & & \\
\hline \multirow[t]{4}{*}{ Weed cover $(\%)^{\dagger}$} & CRI & 2 & 1501.61 & $3.90 \mathrm{NS}$ & \\
\hline & WCT & 1 & 1408.77 & 33.50*** & $\mathrm{NT}>\mathrm{T}$ \\
\hline & $\mathrm{CRI} \times \mathrm{WCT}$ & 2 & 161.42 & 3.84* & \\
\hline & Residuals & 42 & 213.50 & & \\
\hline Winter wheat grain biomass & CRI & 2 & 43232.51 & $10.76^{* * *}$ & $\mathrm{O}<\mathrm{CD}=\mathrm{CS}$ \\
\hline \multirow[t]{2}{*}{$\left(\mathrm{g} 0.25 \mathrm{~m}^{-2}\right)$} & WCT & 1 & 9981.04 & $14.56 * * *$ & $\mathrm{NT}<\mathrm{T}$ \\
\hline & Residuals & 188 & 726.91 & & \\
\hline
\end{tabular}

${ }^{\dagger}$ arcsine-square root transformed

Crop rotation intensity had no significant influence on the number of species of biodiversity value (Table 2.3). Weed control treatment significantly reduced the number of weed species of high biodiversity value in conventional but not in organic rotations (Fig. 2.2 b). 
For total weed cover, a significant interaction between crop rotation intensity and weed control treatment was observed. Weed cover was unaffected by weed control treatment in organic field plots (Table 2.3) but was reduced in the CD and CS plots (Fig. 2.2 c).

(a)

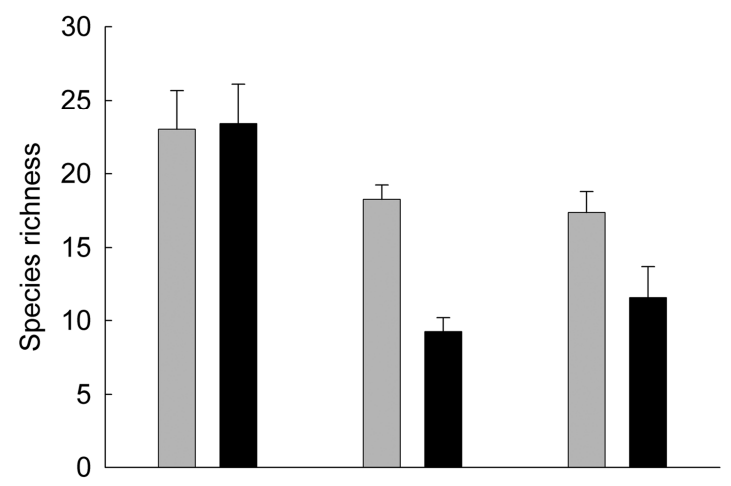

(b)

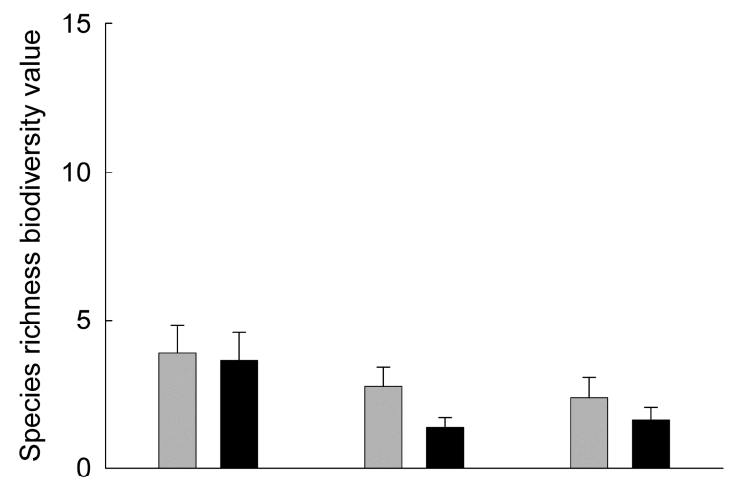

(c)

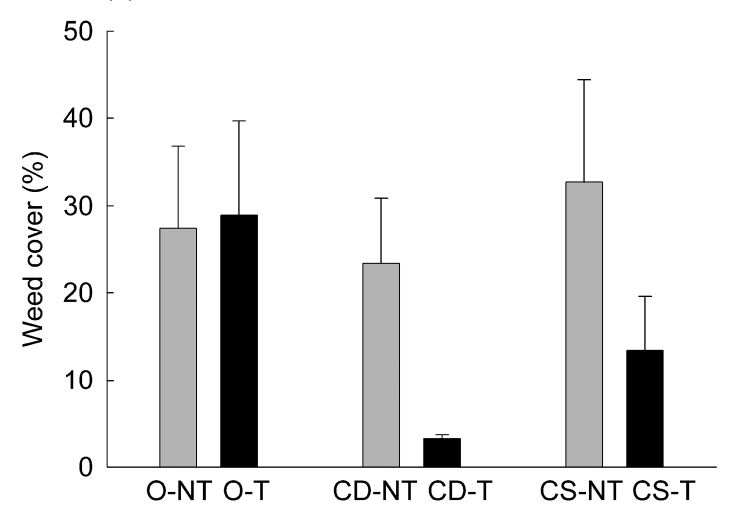

Fig. 2.2 Effect of crop rotation intensity (O, organic crop rotation; $C D$, conventional diverse crop rotation; CS, conventional simple crop rotation) and weed control treatment (NT, without weed control treatment; $\mathrm{T}$, with weed control treatment) on (a) species richness, (b) richness of species of high biodiversity value, and (c) percentage weed cover. Means + SEM are shown.

Grain biomass was significantly lower in organic crop rotation but did not differ between conventional rotations (Table 2.3). Weed control treatment enhanced grain biomass in both 
conventional but not in the organic rotation. The relative effect of weed control treatment was slightly higher in CD compared to the CS crop rotation (Table 2.4).

Table 2.4 Effect and relative effects of weed control treatment on grain biomass of winter wheat assessed by parametric $t$-tests $(\mathrm{n}=24)$. NS, not significant.

\begin{tabular}{lccc}
\hline Weed control treatment & $\begin{array}{l}\text { Mean grain } \\
\text { biomass }\left(\mathrm{g} \mathrm{m}^{-2}\right)\end{array}$ & $\begin{array}{l}\text { Effect relative to } \\
\text { with weed control } \\
\text { treatment }(\%)\end{array}$ & $\begin{array}{l}\text { Significance } \\
\text { between treatments } \\
(t \text {-test })\end{array}$ \\
\hline $\begin{array}{l}\text { Organic } \\
\text { With weed control treatment }\end{array}$ & 203 & -5.0 & NS \\
Without weed control treatment & 193 & & \\
Conventional diverse & & -28.1 & $P<0.01$ \\
$\quad$ With weed control treatment & 414 & & \\
$\quad$ Without weed control treatment & 323 & & $P<0.05$ \\
Conventional simple & & -20.6 & \\
$\quad$ With weed control treatment & 423 & & \\
Without weed control treatment & 351 & & \\
\hline
\end{tabular}

\section{Weed community composition}

The full RDA model including all factors explained $42.4 \%$ of the total variation (Table 2.5). The largest proportion of the explained variation was related to differences between triplets $(23.9 \%)$ and levels of crop rotation intensity $(16.0 \%)$ whereas weed control treatment accounted for a relatively small part of the variation $(2.5 \%)$.

Table 2.5 Linear (partial) RDA models of weed species composition indicating the amount of variation explained by the full model including the factors crop rotation intensity (CRI), weed control treatment (WCT) and triplet (TRI) and each factor separately.

\begin{tabular}{lrrrr}
\hline Factors & Covariables & $\begin{array}{c}\text { \% variation } \\
\text { explained }\end{array}$ & $F$-ratio & $P^{*}$ \\
\hline CRI, WCT, TRI & - & 42.4 & 2.728 & 0.001 \\
CRI & WCT, TRI & 16.0 & 5.127 & 0.001 \\
WCT & CRI, TRI & 2.5 & 1.604 & 0.119 \\
TRI & CRI, WCT & 23.9 & 2.203 & 0.001 \\
\hline
\end{tabular}

*The significance of the RDA models was evaluated using Monte Carlo Permutation Test $(\mathrm{n}=1000$ permutations $)$ 
In the partial RDA ordination diagram describing the unique effect of crop rotation intensity, the first and the second RDA axis explained $13.9 \%$ and $2.0 \%$ of the variation in weed species composition, respectively (Fig. 2.3). In the ordination diagram, Viola arvensis was mainly attributed to CS whereas Epilobium tetragonum and Fumaria officinalis were associated with CD (Fig. 2.3). Vicia hirsuta, Vicia sativa and Taraxacum officinale seem to characterise mainly the organic crop rotation.

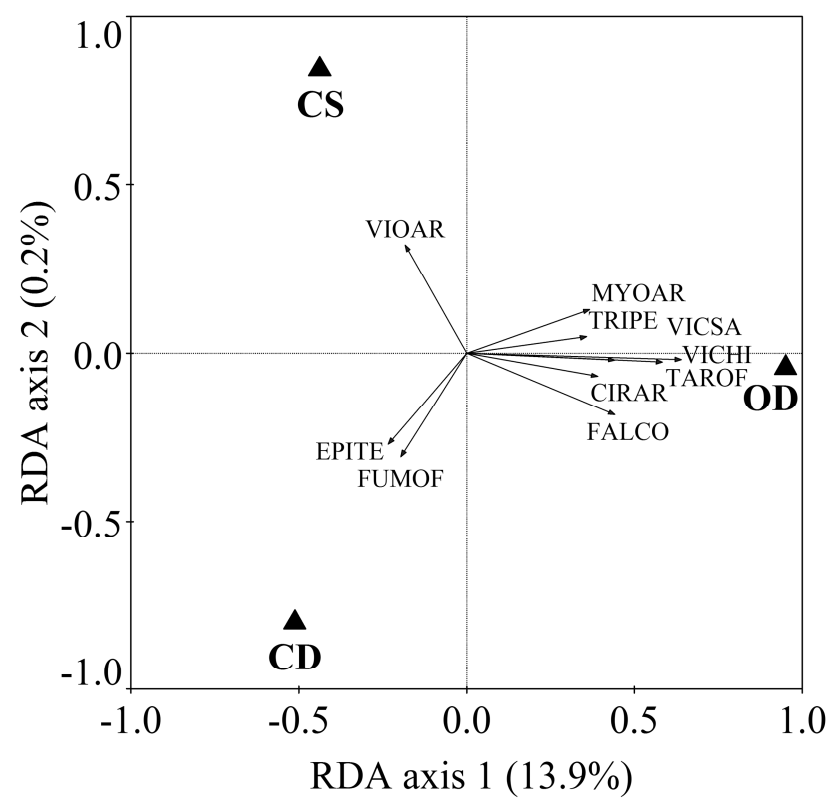

Fig. 2.3 Partial RDA ordination diagram showing the unique effect of crop rotation intensity on weed species composition. Triangles indicate the different crop rotation intensities $(\mathrm{O}$, organic crop rotation; $\mathrm{CD}$, conventional diverse crop rotation; CS, conventional simple crop rotation). Only weed species with $\geq 20 \%$ fit into the ordination subspace (ter Braak \& Smilauer, 2002) are shown. Species codes are: CIRAR, Cirsium arvense; EPITE, Epilobium tetragonum; FALCO, Fallopia convolvulus; FUMOF, Fumaria officinalis; MYOAR, Myosotis arvensis; TAROF, Taraxacum officinale; TRIPE, Tripleurospermum perforatum; VICHI, Vicia hirsuta; VICSA, Vicia sativa; VIOAR, Viola arvensis.

\section{Discussion}

In our on-farm study, we aimed to assess the extent to which diversified crop rotations in intensive conventional systems contribute to higher weed species richness. Our experimental design allowed comparison of the impact of organic and conventional farming systems on weed species richness and composition in winter wheat, by additionally defining different levels of crop rotation intensity within conventional systems. As expected, our results revealed that weed species richness depended mainly on 
the type of farming system, with higher species richness in organic compared to conventional crop rotations. In contrast to our first hypothesis, a higher diversity of crop species in the conventional diverse crop rotation and the inclusion of spring crops did not contribute to higher number of weed species and richness of species of biodiversity value within winter wheat in conventional systems. This could most likely be ascribed to the efficiency of weed management in conventional fields in previous years. As our experimental design was controlled for similar external input levels in both conventional rotations, the influence of temporal crop species diversity on above ground weed species richness was diminished. This is consistent with findings of Menalled et al. (2001) stressing the predominant importance of herbicide use over crop rotation in conventional cropping systems. In other studies, the intensity of chemical weed control was also found to be more important in determining weed species richness compared to the impact of crop rotation in winter wheat (Bàrberi et al., 1997) or in maize, soybean and barley crops (Doucet et al., 1999). Our results therefore indicate that diversified crop rotations in conventional systems might only contribute to higher weed species richness in the longterm when input levels are accordingly reduced. In this context, Smith and Gross (2007) investigated the influence of crop rotation diversity on the diversity of weed species over a 3-year period by excluding any external inputs of pesticides and fertilisers. In their study, however, effects of crop diversity on weed diversity in winter wheat could only be related to the presence of cover crops in the investigated rotations. However, our study was conducted in winter wheat and did therefore not account for the weed flora present within other crops of the rotations. Within the conventional diverse rotation, the effects of spring crops in especially supporting the abundance of spring emerging weeds was not tested by our study design but could be apparent when additionally surveying the spring crops within the rotation. Hence, interactions between external input level, temporal crop species diversity and the type of crop grown in rotation seem to require further investigation.

In accordance to our second hypothesis, herbicide application was regarded the most important effect on weed species richness in conventional crop rotations. This dominant short-term effect of herbicide application is also confirmed by other studies showing decreased weed species numbers and abundance after application of post-emergence herbicides (Moreby \& Southway, 1999; Hald, 1999a). Richness of species of biodiversity value was also reduced by herbicide use in conventional systems which probably impacted on the provision of resource and habitat for insects, potentially resulting in reduced pest control level by beneficial insects (Root, 1973). This is confirmed by studies in winter 
cereal headlands in Great Britain demonstrating that the number of invertebrate taxa, including those important in the diet of farmland birds, was higher in non-treated compared to herbicide-treated plots (Moreby \& Southway, 1999). In plots without weed control, weed species richness in conventional fields was lower than in the organic fields. This probably relates to the long-term extensive management practice, especially the exclusion of herbicides, in organic fields which seems to contribute to higher numbers in the species pool of the soil seed banks (Roschewitz et al., 2005). The one-year abandonment of herbicide use in fields of conventional crop rotations, as conducted in this study, seems not to result in above ground weed species numbers equal to those in organic fields.

The largest proportion of explained variation in weed species composition was attributable to the unique effect of triplet. It is likely that this amount of variation mainly reflects spatial differences between triplets at the landscape scale for which our sampling design did not fully account. The importance of spatial differences in controlling weed species composition in winter wheat has also been pointed out by Hiltbrunner et al. (2008). We suggest that the high proportion in variation explained by crop rotation intensity might mainly be attributed to differences between organic and conventional farming practice which were more important in driving weed species composition than was weed control treatment. Despite the evidence that herbicides strongly affect the composition of weed population by reducing weed species diversity (Haas \& Streibig, 1982), the experimental factor weed control treatment accounted for a rather low proportion of explained variation. The only species associated with CS was $V$. arvensis, a frequent species ranked among the most abundant weeds in German winter cereals (Hanf, 1999) whereas E. tetragonum and F. officinalis were more associated to $\mathrm{CD}$. Of the species showing dependence on organic farming, two were legumes ( $V$. hirsuta, $V$. sativa) which show higher competitive ability in organic systems where nitrogen inputs were lower than in conventional systems (Roschewitz et al., 2005).

As expected, weed control treatment reduced weed cover by $78 \%$ in both conventional crop rotations. Despite mechanical weed control in organic fields, both weed cover and grain biomass did not differ between treated and non-treated plots. This low efficiency of mechanical weed control in the organic study fields was mainly because they were only harrowed once. Higher weed cover in plots without weed control treatment in both conventional crop rotations resulted in lower grain biomass of winter wheat compared to herbicide-treated plots ( $28 \%$ and $21 \%$ reduction for conventional diverse and conventional 
simple crop rotation, respectively). Grain biomass did not differ between conventional simple and conventional diverse crop rotations which is in accordance with results of Smith et al. (2008) in winter wheat showing that yields could not be related to the diversity of crops included in the rotation but were reduced in monocultures.

\section{Conclusion}

Our on-farm study revealed that organic farming resulted in greater weed species richness in winter wheat. However, no pronounced differences in the weed species richness of conventional crop rotations at different intensity levels were observed at the field level. In addition, it must be questioned whether biodiversity conservation can be fully spatially integrated into conventional cropping systems, as current market incentives favour increased agricultural production (Tilman et al., 2002) and appropriate management measures that combine both the maintenance of weed species richness and conservation of species with important ecological functions still require further investigations (Marshall et al., 2003; Storkey \& Westbury, 2007).

\section{Acknowledgements}

This research was carried out as part of the BIOPLEX project and funded by both the German Federal Ministry of Education and Research (BMBF) and the Deutsche Bundesstiftung Umwelt (DBU). Thanks to all farmers for giving permission to work on their fields and to Kirsi Ahrweiler and Bernd Gehlken for help during the fieldwork. We are grateful to three anonymous reviewers for invaluable suggestions on an earlier version of the manuscript.

\section{References}

AEBISCHER NJ (1991) Twenty years of monitoring invertebrates and weeds in cereal fields in Sussex. In: The Ecology of Temperate Cereal Fields, (eds LG Firbank, N Carter, JF Darbyshire \& GR Potts), 305-331. Blackwell Scientific Publications, London, UK.

Altieri MA (1999) The ecological role of biodiversity in agroecosystems. Agriculture, Ecosystems and Environment 74, 19-31. 
Andreasen C, Stryhn H \& Streibig JC (1996) Decline of the flora in Danish arable fields. Journal of Applied Ecology 33, 619-626.

BÀRbERI P, SILVESTRI N \& BONARI E (1997) Weed communities of winter wheat as influenced by input level and rotation. Weed Research 37, 301-313.

Boatman ND, Hart A, Clook M, Brown VK, Holland JM \& Lutman PJW (2003) A risk assessment framework for determining the effects of pesticides on farmland biodiversity. In: The BCPC International Congress: Crop Science and Technology, (eds 239-244. Glasgow, Scotland, UK.

BURNHAM KP \& ANDERSON DA (1998) Model Selection and Inference: a Practical Information-Theoretic Approach, Springer, Berlin, Germany.

CARdina J, Herms CP \& Doohan DJ (2002) Crop rotation and tillage system effects on weed seedbanks. Weed Science 50, 448-460.

DierschKe H (1994) Pflanzensoziologie. Grundlagen und Methoden, Ulmer, Stuttgart, Germany.

Doucet C, Weaver SE, Hamill AS \& Zhang J (1999) Separating the effects of crop rotation from weed management on weed density and diversity. Weed Science 47, 729-735.

HAAS H \& StReibig JC (1982) Changing patterns of weed distribution as a result of herbicide use and other agronomic factors. In: Herbicide Resistance in Plants, (eds HM LeBaron \& J Gressel), 57-79. Wiley, New York, USA.

HAeupler H \& Muer T (2000) Bildatlas der Farn- und Bluetenpflanzen Deutschlands, Ulmer Verlag, Stuttgart, Germany.

HALD AB (1999a) Weed vegetation (wild flora) of long established organic versus conventional cereal fields in Denmark. Annals of Applied Biology 134, 307-314.

HALD AB (1999b) The impact of changing the season in which cereals are sown on the diversity of the weed flora in rotational fields in Denmark. Journal of Applied Ecology 36, 24-32.

HANF M (1999) Ackerunkräuter Europas mit ihren Keimlingen und Samen, VerlagsUnionAgrar, Munich, Germany; Wien, Austria; Zürich, Switzerland.

Hiltbrunner J, Scherrer C, Streit B, Jeanneret P, Zihlmann U \& Tschachtli R (2008) Long-term weed community dynamics in Swiss organic and integrated farming systems. Weed Research 48, 360-369.

Hole DG, Perkins AJ, Wilson JD, Alexander IH, Grice F \& Evans AD (2005) Does organic farming benefit biodiversity? Biological Conservation 122, 113-130. 
HYVÖNEN T \& SALONEN J (2002) Weed species diversity and community composition in cropping practices at two intensity levels - a six-year experiment. Plant Ecology 159, 73-81.

JOLLIFFE PA (1997) Are mixed populations of plant species more productive than pure stands? Oikos 80, 595-602.

LiEBMAN M \& DyCK E (1993) Crop rotation and intercropping strategies for weed management. Ecological Applications 3, 92-122.

LONDO G (1976) Decimal scale for releves of permanent quadrats. Vegetatio 33, 61-64.

Marshall EJP, Brown VK, BoAtman ND, Lutman PJW, SQuire GR \& WARD LK (2003) The role of weeds in supporting biological diversity within crop fields. Weed Research 43, 77-89.

Menalled FD, GRoss KL \& HAmmond M (2001) Weed aboveground and seedbank community responses to agricultural management systems. Ecological Applications 11, 1586-1601.

MoREBy SJ \& SOUTHWAY SE (1999) Influence of autumn applied herbicides on summer and autumn food available to birds in winter wheat fields in southern England. Agriculture, Ecosystems and Environment 72, 285-297.

R Development Core TeAm (2007) R: A language and environment for statistical computing. R Foundation for Statistical Computing. ISBN 3-900051-07-0, URL http://www.R-project.org.

ROBINSON RA \& WILLIAM JS (2002) Post-war changes in arable farming and biodiversity in Great Britain. Journal of Applied Ecology 39, 157-176.

RoOT BR (1973) Organization of a plant-arthropod association in simple and diverse habitats: The fauna of collards (Brassica oleracea). Ecological Monographs 43, 95124.

Roschewitz I, Gabriel D, Tscharntke T \& ThiEs C (2005) The effects of landscape complexity on arable weed species diversity in organic and conventional farming. Journal of Applied Ecology 42, 873-882.

SATtLer C, KäChele H \& Versch G (2006) Assessing the intensity of pesticide use in agriculture. Agriculture, Ecosystems \& Environment 119, 299-304.

SMITH RG \& GROSS KL (2006) Weed community and corn yield variability in diverse management systems. Weed Science 54, 106-113.

SMITH RG \& GROSS KL (2007) Assembly of weed communities along a crop diversity gradient. Journal of Applied Ecology 44, 1046-1056. 
SMith RG, GROSS KL \& ROBERTSON GP (2008) Effects of crop diversity on agroecosystem function: Crop yield response. Ecosystems 11, 355-366.

SquiRE GR, Rodger S \& WRIGHT G (2000) Community-scale seedbank response to less intense rotation and reduced herbicide input at three sites. Annals of Applied Biology 136, 47-57.

STORKEY J (2006) A functional group approach to the management of UK arable weeds to support biological diversity. Weed Research 46, 513-522.

Storkey J \& Westbury DB (2007) Managing arable weeds for biodiversity. Pest Management Science 63, 517-523.

TER BRAAK CJF \& SMILAUER P (2002) CANOCO Reference Manual and CanoDraw for Windows User's Guide: Software for Canonical Community Ordination (version 4.5). Microcomputer Power. Ithaca, New York.

THOMPSON K \& GRIME JP (1979) Seasonal variation in the seed banks of herbaceous species in ten contrasting habitats. Journal of Ecology 67, 893-921.

Tilman D, Cassman KG, Matson PA, Naylor R \& Polasky S (2002) Agricultural sustainability and intensive production practices. Nature 418, 671-677. 


\section{CHAPTER}

3

Using selective herbicides to manage beneficial and rare weed species in winter wheat

Lena Ulber, Horst-Henning Steinmann \& Sebastian Klimek 


\begin{abstract}
Weed species within arable farming systems act as a source of food and provide habitat for various taxa at higher trophic levels. Using field experiments in winter wheat, we investigated whether selective herbicides can be used as a potential tool for sustaining beneficial, less competitive weed species and rare species of high conservation value while controlling highly competitive weed species. We tested three selective herbicides with different active ingredients (amidosulfuron + iodosulfuron, fluroxypyr, mecoprop-P) at two application rates. We analysed cover of selected focal species (Centaurea cyanus and Papaver rhoeas) as well as weed species richness, winter wheat yield and weed community composition as influenced by herbicide treatments. Herbicide treatments involving fluroxypyr generally allowed for the selective retention of the regionally threatened weed species $C$. cyanus and P. rhoeas, as a beneficial species of high value for associated trophic level, and provided considerable control of the competitive species G. aparine. Herbicide treatments significantly affected weed species composition. The PRC method clearly showed the time-dependent herbicide treatment effects on weed community composition and allowed an estimate of the variance in species composition that is explained by the herbicide treatments. Our results indicated that applying selective herbicides can provide a feasible option for in-crop management of weed diversity by retention of beneficial or rare weed species occurring at moderate densities and control of highly-competitive weeds. However, weed control strategies must be tailored to sitespecific conditions to account for increased abundance of competitive species.
\end{abstract}

Keywords: biodiversity, Centaurea cyanus, Galium aparine, Papaver rhoeas, Principal Response Curve, weed control 


\section{Introduction}

Besides their detrimental impact on crop yield and quality, weed species within arable farming systems can serve as a resource of food and habitat for higher-level taxa, such as granivorous birds and phytophagous insects (HAWES et al. 2003; MARSHALL et al. 2003), which in turn provide food for predatory farmland birds (CHAMBERLAIN et al. 2000). Moreover, weed species add structural habitat diversity to the crop environment (HAWES et al. 2003) and can contribute to control of crop pests through enhancement of natural enemies (MARshall and MoONEn 2002). In Europe, a general decline in arable weed diversity has been observed in recent decades caused by agricultural intensification. High weed control efficacy has been attributed mainly to herbicides, such as those belonging to the phenoxy acids and sulfonylureas that target a wide range of broad-leaved weeds (HYVÖNEN et al. 2003). As a consequence, weed species, such as Centaurea cyanus L., have declined sharply in most parts of North-West Europe (HÅKANSSON 2003).

In the vast majority of cropping systems in Western Europe, weeds are controlled to enhance crop yield and quality, to facilitate harvest or to prevent the build-up of long-term weed seed banks. Typical weed communities in cereal-based crop rotations are composed of highly competitive species, such as Bromus spp., Fallopia convolvulus (L.) Å. Löve and Galium aparine L., which can substantially reduce crop quality and yield, even when occurring at low densities. However, many weed communities in cereal crops include species that are not associated with significant yield losses, except when occurring at very high densities (WeSTBURY et al. 2008). Among those weed species are species that have been considered to be beneficial as they serve as a resource for higher taxa, such as beneficial arthropods and pollinators, as well as rare weed species that justify conservation, given their status as threatened species (STORKEY and WESTBURY 2007).

The total omission of herbicide applications with the aim of supporting certain desirable species may lead to high densities of all weed species, including competitive ones with a negative impact on crop production. A more tailored approach of in-crop weed management may combine control of pernicious weeds with retention of beneficial or rare species occurring at moderate densities (WESTBURY et al. 2008; SMITH et al. 2009). Against this background, one possible management strategy is the use of selective herbicide treatments (LUTMAN 2005; JONES and SMITH 2007). In this context, the term selective refers to herbicides not only selective against certain crop species, but also less active on some weed species. As weed species differ in their sensitivity towards various 
active ingredients, they are differentially controlled by the same herbicide treatment. In conservation headlands, the use of selective herbicides enhanced weed species that provide food for invertebrates and, therefore, increased the fledging successes of game birds (AEBISCHER 1997). However, some farmland bird species, such as skylarks (Alauda arvensis), avoid field boundaries and forage within the inner field (DE SNOO and LUTTIK 2004). This highlights the potential of an in-crop approach for conservation of beneficial and rare weed species within arable fields. Weed species richness and community composition can impact also on the diversity of higher trophic levels (ASTERAKI et al. 2004). Results from the so-called SAFFIE project in the UK have shown that a single herbicide application in spring contributed to higher weed species richness compared to a sequence of herbicides and this, in turn, resulted in a higher invertebrate abundance (JONES et al. 2007).

The objective of this study was to experimentally test the use of selective herbicides as a potential tool for sustaining beneficial, less competitive weed species and rare species of high conservation value, while at the same time, controlling highly competitive, pernicious weeds. Two experiments with differing focal species were conducted. In the first experiment (CENCY-experiment), we focused on maintaining C. cyanus; a regionally rare arable species that, in addition to its status as a threatened species, can provide habitat to pollinators (PERJU and MOLDOVAN 1991), and beneficial arthropods, such as aphidophagous syrphids (WEISS and STETTMER 1991) and anthocorids (FITZGERALD and SOLOMON 2004). The frequency and abundance of $C$. cyanus has declined considerably in many regions during recent decades and C. cyanus is now listed as a Red List species in the study region in Lower Saxony, Germany. The second experiment (PAPRH-experiment) aimed at controlling the pernicious species G. aparine, the main target in spring, while encouraging Papaver rhoeas L., which is a beneficial species characterised by an intermediate competitive ability (STORKEY and WESTBURY 2007). Papaver rhoeas is pollinated by different bee species (FREE 1993) and visited by various species of Coleoptera and Hymenoptera (FREI and MANHART 1992). In both experiments, we further investigated the impact of herbicide treatment on weed species richness and community composition. In order to analyse treatment-induced changes within the weed communities during the growing period, we used the multivariate principal response curve (PRC) method and evaluated whether the use of PRC could provide additional important insights into herbicide treatment effects. 


\section{Materials and Methods}

\section{Focal weed species}

The two experiments were conducted in 2008 in two winter wheat fields at commercial farms in the administrative district of Northeim in Lower Saxony, Germany. Both selected sites were chosen with respect to the occurrence of the focal weed species and cropping history (>20 years). In the district of Northeim, mean annual precipitation is $645 \mathrm{~mm}$ and mean annual temperature $8.7{ }^{\circ} \mathrm{C}$ (DEUTSCHER WETTERDIENST 2008). In both the CENCYexperiment (focal weed species: C. cyanus) and the PAPRH-experiment (focal weed species: P. rhoeas), all weed species other than the focal species or G. aparine (PAPRHexperiment) were grouped and labelled as 'other species' (Table 3.1). This group consisted mainly of undesirable, competitive species such as Cirsium arvense (L.) Scop. and Veronica spp..

Table 3.1 Weed species cover in the CENCY-experiment and the PAPRH-experiment prior to herbicide application in April 2008. Focal weed species are shown in bold. Means \pm SEM are given.

\begin{tabular}{lrr}
\hline Scientific name & \multicolumn{2}{c}{ Mean weed cover (\%) } \\
& Expt 1 & \multicolumn{1}{c}{ Expt 2 } \\
\hline Centaurea cyanus & $7.6 \pm 0.6$ & - \\
Cerastium glomeratum & $0.3 \pm 0.1$ & - \\
Cirsium arvense & - & $2.6 \pm 0.4$ \\
Galium aparine & - & $\underline{7.7 \pm 1.7}$ \\
Lamium amplexicaule & - & 0.4 \\
Lamium purpureum & $0.6 \pm 0.1$ & $1.0 \pm 0.3$ \\
Matricaria recutita & $1.0 \pm 0.2$ & $0.6 \pm 0.2$ \\
Myosotis arvensis & $0.8 \pm 0.2$ & $0.2 \pm 0.1$ \\
Papaver rhoeas & $0.3 \pm 0.1$ & $9.1 \pm 0.8$ \\
Stellaria media & $0.2 \pm 0.1$ & $0.2 \pm 0.1$ \\
Veronica hederifolia & $1.8 \pm 0.4$ & $1.9 \pm 0.7$ \\
Veronica persica & $1.8 \pm 0.2$ & - \\
Viola arvensis & $0.1 \pm 0.0$ & $3.2 \pm 0.3$ \\
\hline
\end{tabular}

\section{Experimental design}

At each site, plots were laid out according to a complete randomised block design with four replicated blocks. Experimental blocks were $90 \mathrm{~m}^{2}$ with an individual plot size of 
$10 \mathrm{~m}^{2}(2 \mathrm{~m} \times 5 \mathrm{~m})$. On both sites, the preceding crop had been winter wheat. Fields were cultivated using spring tine cultivation prior to planting of winter wheat (Table 3.2).

Table 3.2 Location of experiments, soil type and management treatments applied in winter wheat in the CENCY-experiment and the PAPRH-experiment in 2007/08.

\begin{tabular}{lll}
\hline & Expt 1 & Expt 2 \\
\hline Geographical location & $51^{\circ} 36^{\prime} \mathrm{N}$ and $9^{\circ} 56^{\prime} \mathrm{E}$ & $51^{\circ} 47^{\prime} \mathrm{N}$ and $9^{\circ} 50^{\prime} \mathrm{E}$ \\
Soil type & Gleyed luvisol & Luvisol \\
Preceding crop & Winter wheat & Winter wheat \\
Primary tillage (spring-tine cultivation) & 08 October 2007 & 23 September 2007 \\
Cultivar & Tommi & Dekan \\
Sowing date & 15 October 2007 & 25 September 2007 \\
Sowing density & 400 seeds $\mathrm{m}^{-2}$ & 400 seeds $\mathrm{m}^{-2}$ \\
Herbicide application & 18 April 2008 & 22 April 2008 \\
\hline
\end{tabular}

In neither experiment were herbicides applied in autumn. In April, a treatment of pinoxaden plus cloquintocet-mexyl as safener (Axial 50, 50:12.5 $\mathrm{g} \mathrm{L}^{-1}$, SYNGENTA) was applied at $90 \mathrm{~g}$ active ingredient per hectare to all plots. This treatment successfully controlled grass species, especially Alopecurus myosuroides Huds.. Herbicides were selected based on their low efficacy against the focal weed species $C$. cyanus and $P$. rhoeas, and their high efficacy against $G$. aparine. Herbicide treatments were identical for both experiments. As reduced herbicide doses have been widely adopted in some European countries, due to environmental concerns and financial pressure on farmers (KUDSK and StREIBIG 2003), we also tested reduced herbicide rates. The six treatments consisted of three herbicides applied at two rates (100 and 50\% of recommended rate). One untreated control treatment was included (Table 3.3). Amidosulfuron + iodosulfuron (Hoestar Super, 125:25 $\mathrm{g} \mathrm{kg}^{-1}$, BAYER CROPSCIENCE), fluroxypyr (Starane 180, $180 \mathrm{~g} \mathrm{~L}^{-1}$, Dow AGROSCIENCE) and mecoprop-P (Duplosan KV, $600 \mathrm{~g} \mathrm{~L}^{-1}$, DuPONT) were applied in April 2008 when weeds were at the six- to eight-leaf stage. The product combination of amidosulfuron + iodosulfuron included mefenpyr as a safener at $106 \mathrm{~g} \mathrm{~kg}^{-1}$. Herbicide treatments were applied with a $\mathrm{CO}_{2}$-pressurised backpack sprayer with a 2-m boom equipped with Turbo TeeJet TT11002-M nozzle tips (TeEJet Technologies GmBh, Ludwigsburg, Germany) calibrated to deliver $400 \mathrm{~L} \mathrm{ha}^{-1}$ of water at $200 \mathrm{kPa}$. 
Table 3.3 Herbicide and dose rates applied in the CENCY-experiment and the PAPRH-experiment in April 2008.

\begin{tabular}{crlr}
\hline Treatment & Dose rate & Active ingredient & a. i. $\left(\mathrm{g} \mathrm{ha}^{-1}\right)$ \\
\hline Control & - & - & - \\
AI-100 & $100 \%$ & Amidosulfuron & 25.0 \\
& & + Iodosulfuron & 2.4 \\
& & + Safener: mefenpyr & 21.2 \\
AI-50 & $50 \%$ & Amidosulfuron & 12.5 \\
& & + Iodosulfuron & 1.2 \\
& & + Safener: mefenpyr & 10.6 \\
Fx-100 & $100 \%$ & Fluroxypyr & 180.0 \\
Fx-50 & $50 \%$ & Fluroxypyr & 90.0 \\
Mp-100 & $100 \%$ & Mecoprop-p & 1200.0 \\
Mp-50 & $50 \%$ & Mecoprop-p & 600.0 \\
\hline
\end{tabular}

\section{Weed and crop yield assessments}

For estimation of weed cover, five permanent quadrats $(0.1 \mathrm{~m} \times 0.1 \mathrm{~m})$ were randomly placed in each experimental plot. Within each quadrat, percentage plant cover of each weed species was estimated prior to application of the herbicide treatments (Table 3.1). Assessments of treatment effects on weed cover were carried out three times throughout the growing season, at regular intervals from May to July. Weed species richness was expressed as the total number of weed species per plot.

We analysed grain yield of winter wheat to assess the interaction between increased focal weed species cover and crop yields. Therefore, data on grain yields of winter wheat and weed biomass were obtained in the CENCY-experiment. In this experiment, the reduction in crop yield could be explained directly by the plant cover of the focal species $(C$. cyanus), as other weed species occurred only at low densities (Table 3.1). Biomass samples of winter wheat grain and C. cyanus were taken from four $0.5 \mathrm{~m} \times 0.5 \mathrm{~m}$ quadrats in each plot just after the final weed cover assessment. Samples were dried at $105^{\circ} \mathrm{C}$ for $24 \mathrm{~h}$ and winter wheat ears were mechanically threshed and weighed.

\section{Statistical analysis}

As the two experiments differed in focal weed species, soil type and wheat cultivar, they were analysed as separate experiments with replication of measurements applied within each experiment. Linear mixed-effects models were fitted in $R$ ( $R$ DEVELOPMENT CORE 
TEAM 2007). Maximum likelihood (ML) was used within the linear mixed-effects models, because both experiments were balanced and had an orthogonal design. Herbicide treatment was included as a fixed factor and block as a random factor. Weed cover prior to herbicide treatment was used as a covariate to adjust for initial differences in weed growth. In both experiments, treatment effects on total weed species richness were analysed. In the CENCY-experiment, cover and biomass of C. cyanus, cover of 'other species' and biomass of winter wheat grain were used as response variables. In the PAPRH-experiment, cover of P. rhoeas, G. aparine and 'other species' were analysed. For all response variables, data from the last weed assessment in July were used. Percent cover was arcsine-square root transformed prior to analysis to reduce heteroscedasticity and account for non-normality of errors. The interaction between the covariate initial weed cover and herbicide treatment was not significant in any of the models and was, therefore, removed during the process of model simplification. The appropriateness of each final model was checked by plotting standardised residuals against fitted values (not shown). When the effect of herbicide treatment was significant, analysis of contrasts was used to compare each treatment against the control plot.

To further examine treatment effects on changes in weed species composition during the growth season, a multivariate Principal Response Curve (PRC) method was used (VAN DEN BRINK and TER BRAAK 1999). PRC is based on redundancy analysis (RDA), adjusted for overall changes in community response over time. The method enables to focus on that part of the variance explained by herbicide treatment relative to the untreated control. The program CANOCO (Version 4; TER BRAAK and SMILAUER 2002) was used to perform the partial RDA, construct the PRC and test for treatment differences in community composition using a Monte Carlo permutation test $(n=1000)$. In the PRC diagram, treatment effects are plotted against assessment dates (VAN DEN BRINK and TER BRAAK 1999; TER BRAAK and SMILAUER 2002). Species weights were used to identify those weed species that had a high affinity to the treatments relative to the control plots. In the PRC diagram, the canonical coefficients (Cdt) quantify the compositional difference between the control and other treatments at each sampling date. Species weights shown in the right hand part of the diagrams represent the affinity of each given species to the response shown. Responses of weed species with larger positive weights were interpreted to follow the overall patterns shown by the PRC, whereas species with larger negative weights were inferred to show the opposite pattern. Species with weights near zero (-0.5 to 0.5$)$ were 
considered to have either no response or one that was unrelated to the pattern shown by the PRC (TER BRAAK, 2002).

\section{Results and Discussion}

Species richness

Total initial weed cover averaged over all plots was $14.0 \% \pm 0.7$ (mean \pm SEM) in the CENCY-experiment and 26.7\% \pm 1.6 in the PAPRH-experiment (Table 3.1). Weed species richness prior to application of herbicide treatment was $4.6 \pm 0.3$ and $4.8 \pm 0.3$ per quadrat in the CENCY-experiment and the PAPRH-experiment, respectively.

Herbicide treatment did not significantly affect weed species richness in either experiment (Table 3.4). Similar to results obtained by DERKSEN et al. (1995), selective herbicide products may have suppressed cover of certain species rather than eliminating them from the aboveground species pool. This may have resulted in similar species richness across treatment plots, as observed in our experiments. However, some weed species, such as $G$. aparine, were completely controlled by the herbicide treatment. Weed species richness is positively related to invertebrate species richness (ASTERAKI et al. 2004). However, the presence of certain weed species can be more important in maintaining invertebrate diversity than other weed species, as has been shown for butterflies (PYWELL et al. 2004), and parasitoids (RUSSELL 1989). In the case of butterflies, this can be explained by the fact that some weed species serve as a better host to the caterpillars or as a better source of nectar to the adults. Encouraging single weed species that have a beneficial attribute for a higher trophic level may, therefore, be equally important as targeting high overall species richness.

\section{CENCY-experiment}

In the CENCY-experiment, herbicide treatment significantly affected cover of C. cyanus but not of 'other species' (Table 3.4). The lowest $C$. cyanus cover was observed after the full dose of mecoprop-P (Mp-100). Both doses of amidosulfuron + iodosulfuron and fluroxypyr suppressed, but not completely controlled, C. cyanus (Table 3.5). As both doses of amidosulfuron + iodosulfuron and the full dose of fluroxypyr considerably reduced cover of 'other species', these treatments seem to be promising with respect to weed control and in-crop management of the regionally rare species $C$. cyanus. 
Table 3.4 Summary of analyses of linear mixed-effects models on the effects of selective herbicide treatments in winter wheat on various response variables used in the CENCY-experiment and the PAPRH-experiment. Non significant interaction terms were excluded during model simplification. Significance levels are $* * * P<0.001 ; * * P<0.01 ; * P<0.05$; NS, not significant.

\begin{tabular}{|c|c|c|c|c|}
\hline & Source & d.f. & MS & $F$ \\
\hline \multicolumn{5}{|l|}{ Expt 1} \\
\hline \multirow[t]{2}{*}{ Species richness } & Herbicide treatment & 6 & 2.31 & $2.31 \mathrm{NS}$ \\
\hline & Residuals & 21 & 1.00 & \\
\hline \multirow[t]{3}{*}{ Centaurea cyanus $(\% \text { cover })^{\mathrm{a}}$} & Herbicide treatment & 6 & 167.84 & $10.92 * * *$ \\
\hline & Initial cover & 1 & 344.24 & $22.36^{* * *}$ \\
\hline & Residuals & 17 & 15.39 & \\
\hline \multirow[t]{3}{*}{ 'Other species' ( $\%$ cover $)^{a}$} & Herbicide treatment & 6 & 92.08 & $1.81 \mathrm{NS}$ \\
\hline & Initial cover & 1 & 22.10 & $0.43 \mathrm{NS}$ \\
\hline & Residuals & 17 & 50.93 & \\
\hline \multirow[t]{2}{*}{ Biomass C. cyanus $\left(\mathrm{g} \mathrm{m}^{-2}\right)$} & Herbicide treatment & 6 & 17869.52 & $22.41 * * *$ \\
\hline & Residuals & 21 & 797.84 & \\
\hline \multirow[t]{2}{*}{ Biomass winter wheat grain $\left(\mathrm{g} \mathrm{m}^{-2}\right)$} & Herbicide treatment & 6 & 34281.34 & $4.79 * *$ \\
\hline & Residuals & 21 & 7156.83 & \\
\hline \multicolumn{5}{|l|}{ Expt 2} \\
\hline \multirow[t]{2}{*}{ Species richness } & Herbicide treatment & 6 & 2.08 & $1.52 \mathrm{NS}$ \\
\hline & Residuals & 21 & 1.36 & \\
\hline \multirow[t]{3}{*}{ Papaver rhoeas $(\% \text { cover })^{a}$} & Herbicide treatment & 6 & 355.42 & $12.02 * * *$ \\
\hline & Initial cover & 1 & 463.62 & $15.69 * *$ \\
\hline & Residuals & 17 & 29.55 & \\
\hline \multirow[t]{3}{*}{ Galium aparine $(\% \text { cover })^{\mathrm{a}}$} & Herbicide treatment & 6 & 768.25 & $8.52 * * *$ \\
\hline & Initial cover & 1 & 389.00 & $4.32 \mathrm{NS}$ \\
\hline & Residuals & 17 & 90.27 & \\
\hline \multirow[t]{3}{*}{ 'Other species' ( $\%$ cover $)^{a}$} & Herbicide treatment & 6 & 254.97 & $1.96 \mathrm{NS}$ \\
\hline & Initial cover & 1 & 507.56 & $3.91 \mathrm{NS}$ \\
\hline & Residuals & 17 & 129.89 & \\
\hline
\end{tabular}

Annotations: aarcsine-square root transformed; d.f., degrees of freedom; MS, mean square 
Our study demonstrated that application of certain herbicide treatments could conserve C. cyanus on fields where it occurs naturally. This finding could help to counteract the ongoing loss of weed biodiversity in the agricultural landscape in North-West Europe (WILSON 2007). Our result is in agreement with findings of JONES et al. (2007), who also demonstrated that the most suitable herbicide treatment for broader in-crop biodiversity was a single spring application of amidosulfuron.

\section{C. cyanus biomass $\left(\mathrm{g} \mathrm{m}^{-2}\right)$}

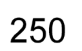

250

200

150

100

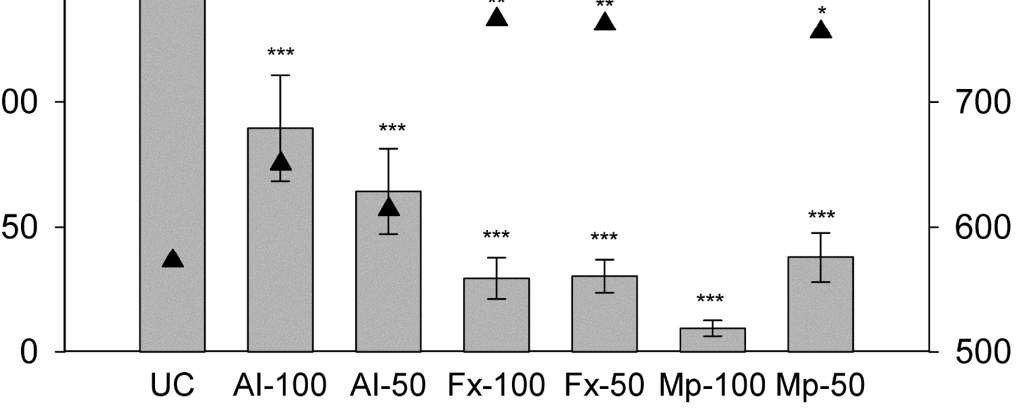

Herbicide treatment
Winter wheat

grain yield $\left(\mathrm{g} \mathrm{m}^{-2}\right)$

C. cyanus biomass

A Winter wheat grain yield

1000

900

800

00

600

Figure 3.1 Effect of herbicide treatment on biomass of Centaurea cyanus and grain yield of winter wheat in the CENCY-experiment. For abbreviation of herbicide treatments see Table 3.3. Stars indicate a significant difference from the control treatment. Significance levels are $* * * P<0.001$; $* * P<0.01 ; * P<0.05 ;$ no asterisk means not significant.

A significant effect of herbicide treatment was also observed on biomass of C. cyanus (Table 3.4, Fig. 3.1), and on biomass of winter wheat grain (Table 3.4). Higher grain yields of winter wheat were found in plots with reduced biomass of C. cyanus (Fig. 3.1). Compared to the control plots, the most effective herbicide treatment, namely full dose of mecoprop-P, resulted in $46 \%$ more grain biomass. Winter wheat yields were significantly higher after the full fluroxypyr than after the amidosulfuron + iodosulfuron treatment. 
Table 3.5 Mean plant cover (back-transformed percentage values (SEM)) of the rare arable species C. cyanus and 'other species' in the CENCY-experiment, and of the beneficial species P. rhoeas, the pernicious species G. aparine and 'other species' in the PAPRH-experiment, as influenced by herbicide treatments. For abbreviation of herbicide treatments see Table 3.3. Significance levels are $* * * P<0.001 ; * * P<0.01 ; * P<0.05 ; \mathrm{NS}$, not significant.

\begin{tabular}{llllll}
\hline \multicolumn{5}{c}{ Exp 1 } & \multicolumn{4}{c}{ Exp 2 } \\
\hline Treatment & $\begin{array}{l}\text { Centaurea } \\
\text { cyanus }\end{array}$ & Other species & Papaver rhoeas & Galium aparine & Other species \\
\hline UC & 49.94 (4.15) & $10.06(4.15) \mathrm{NS}$ & $32.94(6.21)$ & $37.92(3.70)$ & $44.57(19.69) \mathrm{NS}$ \\
AI-100 & $31.97(5.63)^{*}$ & $2.77(2.49) \mathrm{NS}$ & $3.53(2.34) * * *$ & $8.75(2.75)^{* *}$ & $21.55(4.74) \mathrm{NS}$ \\
AI-50 & $29.01(6.08) \mathrm{NS}$ & $1.50(1.19) \mathrm{NS}$ & $7.93(2.90) * * *$ & $25.67(7.99) \mathrm{NS}$ & $24.22(3.85) \mathrm{NS}$ \\
Fx-100 & $25.65(6.08)^{*}$ & $1.15(0.53) \mathrm{NS}$ & $12.75(5.36) * * *$ & $0.00(0.00) * * *$ & $22.31(3.24) \mathrm{NS}$ \\
Fx-50 & $28.15(4.31)^{*}$ & $7.23(3.37) \mathrm{NS}$ & $21.60(8.40) \mathrm{NS}$ & $5.00(2.56) * * *$ & $52.02(8.89) \mathrm{NS}$ \\
Mp-100 & $2.87(0.80)^{* * *}$ & $3.74(1.94) \mathrm{NS}$ & $3.83(2.83) * * *$ & $8.50(3.50)^{* *}$ & $22.03(3.68) \mathrm{NS}$ \\
Mp-50 & $15.55(0.50)^{* *}$ & $3.27(0.92) \mathrm{NS}$ & $10.41(4.59) * * *$ & $10.55(0.80)^{*}$ & $36.15(9.96) \mathrm{NS}$ \\
\hline
\end{tabular}

\section{PAPRH-experiment}

Although $P$. rhoeas has been described as a species of intermediate competitive ability (STORKEY and WeSTBURY 2007), a high percentage cover was observed in control plots of the PAPRH-experiment (Table 3.5). Cover of P. rhoeas and G. aparine was significantly affected by herbicide treatments (Table 3.4). Papaver rhoeas was significantly suppressed by all herbicide treatments, except fluroxypyr (Fx-50) at half dose (Table 3.5). However, control of P. rhoeas by the tested herbicide treatments was not complete. TORRA et al. (2008) also observed that an annual application of a single post-emergence herbicide was insufficient to completely control $P$. rhoeas, even though control efficacy was high. In addition, the seed production output of $P$. rhoeas is considerably high $(>6000$ seeds per single plant; TORRA et al. 2008) and the reduction in viability of seeds in different soils is less than 20\% per year (LUTMAN et al. 2002). This indicates that P. rhoeas has the ability to reproduce and, therefore, persist in cropping systems, even if controlled to a high degree by herbicide applications, such as the full dose of fluroxypyr in our experiment. Although enhanced cover of $P$. rhoeas can promote the abundance of flower-visiting insects, such as hover-flies and butterflies (DE SNOO 1995), it is still unknown how much weed cover is actually required to ensure a sufficient provision of pollen and nectar resources. 
The fluroxypyr treatment (Fx-100) encouraged the beneficial species $P$. rhoeas, but controlled the competitive species G. aparine (Table 3.5). Similar to results obtained by JONES et al. (2007), G. aparine was also significantly reduced by a full dose of amidosulfuron + iodosulfuron. Regrowth of $G$. aparine after sulfonylurea injury was observed for a few plants at full dose, and for most plants at half dose. In our experiment, however, the amidosulfuron + iodosulfuron treatment significantly suppressed $P$. rhoeas and was less effective against G. aparine than fluroxypyr. Under the site-specific conditions of the PAPRH-experiment, application of a full dose of fluroxypyr, therefore, seems most suitable to maintain beneficial weed species while controlling pernicious ones. No significant effect of herbicide treatment was observed for 'other species' (Table 3.4). A half dose of fluroxypyr (Fx-50) and mecoprop-P (Mp-50) failed to reduce cover of 'other species' compared to the control (Table 3.5). Even after application of a full dose of fluroxypyr, cover of 'other species' was considerably high and, therefore, likely to influence crop yield.

\section{Species composition}

Weed community composition changed after all herbicide treatments compared to the control plots (Fig. 3.2 a, b). In both experiments, the first PRC axis was significant (Monte Carlo permutation test, $P<0.05)$ and explained most of the variation in weed species composition. The second axis explained less than $2 \%(P>0.05)$.

In the CENCY-experiment, $24 \%$ of the total variation was explained by herbicide treatment and $10 \%$ by assessment date. At the final assessment date, weed communities in plots that received a full dose of mecoprop-P (Mp-100) differed most from those in control plots (Fig. 3.2 a). In the PRC diagram, Centaurea cyanus showed a highly negative weight for the first PRC axis, indicating that this species strongly responded to the herbicide treatments. The highest control efficacy was achieved after mecoprop-P at full dose. These results support those obtained by the univariate analyses where the full mecoprop-P treatment showed the highest efficacy against C. cyanus. Veronica persica and Matricaria recutita also responded to the treatments, but the remaining species responded indifferently $(-0.5$ to +0.5$)$. 

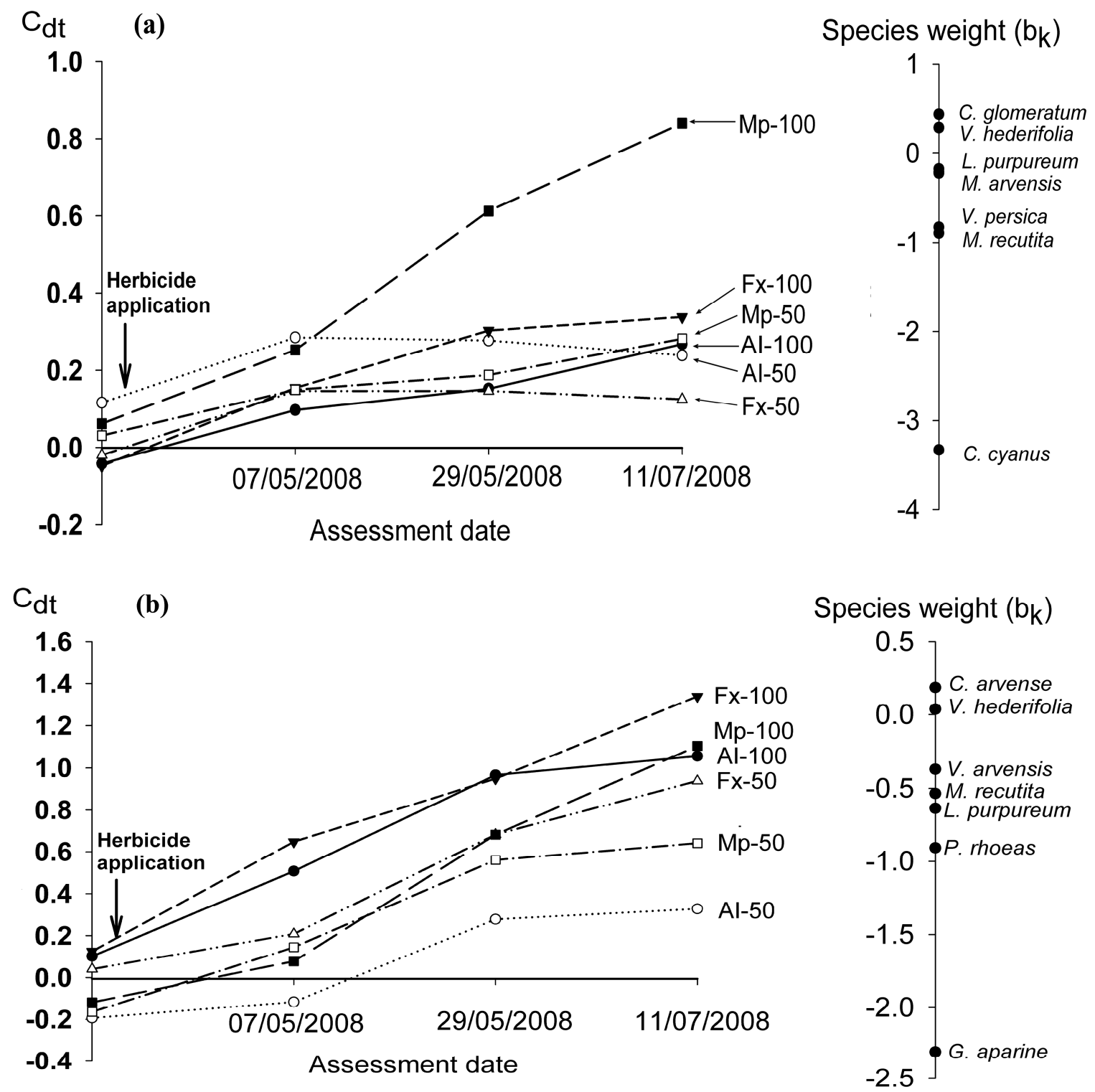

Figure 3.2 Principal response curve (PRC) diagrams showing the time-dependent response of weed community composition to different herbicide treatments with species weights indicating the response of individual species. The first component of the PRC is shown for the CENCYexperiment (a) and the PAPRH-experiment (b), using the control treatment as an internal reference. For abbreviation of herbicide treatments see Table 3.3.

In the PAPRH-experiment, all herbicide treatments affected species composition similarly (Fig. 3.2 b). Of the total variation, $26 \%$ was explained by herbicide treatment and $8 \%$ by sampling date. Most of the species had negative weights, indicating that they declined in the treated plots relative to the control. According to both the univariate and the PRC analyses, G. aparine responded strongest to the treatments, especially to fluroxypyr (Fx100). According to the PRC analysis, the response of $P$. rhoeas was intermediate between 
G. aparine and 'other species'. Species weights of Veronica arvensis, Matricaria recutita and Lamium purpureum ranged from +0.2 to -0.6 , indicating that those species only responded weakly to herbicide treatment in the PAPRH-experiment. This is consistent with results of the univariate analysis, which indicated no significant effect of herbicide treatment on 'other species'.

The PRC method clearly showed the time-dependent herbicide treatment effects on weed community composition and allowed an estimate of the variance in species composition that is explained by the herbicide treatments. In recent studies of grassland communities, PRC has already been successfully applied to analyse the effects of treatments over time (JONGEPIEROVA et al. 2007; MACCHERINI et al. 2007). Hence, the PRC method offers a relatively simple possibility to monitor and interpret effects of any weed control measures on weed community composition and provides an interesting alternative, particularly if used in a complementary manner with traditional regression methods.

\section{Implications for practical weed management}

Our results are congruent with the findings of JONES et al. (2007) and STORKEY and WESTBURY (2007) who demonstrated that herbicides with a high specificity provided a valuable contribution to the development of environmentally targeted weed management systems. These management systems may enhance the ecological benefits derived from weeds. In this study, the experimental treatments were not replicated over time. Instead, we choose to focus on interannual variation within experimental sites. Nevertheless, we believe that the lack of replication did not reduce the general relevance of our findings. The selectivity of herbicides has already been documented and validated by numerous field experiments, conducted by both herbicide manufacturers and various consultancy services (e.g. DAVIES 2003). There are, however, clear obstacles to a widespread adoption of selective herbicide application by farmers. Although a single herbicide product could be used to preserve multiple weed species, the choice of herbicides will be highly depended on the presence of desirable and competitive species as well as the availability of suitable selective herbicides. Especially when the background weed flora is diverse, the selection of appropriate herbicide products can be challenging for farmers in terms of practical and financial feasibility. In addition, the presence of other, highly abundant, or herbicide resistant species might lead to a build-up of those weed species in subsequent crops. Such a build-up may, in turn, magnify crop management problems in future years. The proposed 
herbicide treatments can, therefore, not be applied without regard to site-specific weed infestations that could impact on the durability of selective herbicide strategies. Furthermore, selective herbicide treatments were accompanied by a reduction in winter wheat yields, as shown in the CENCY-experiment. Hence, compensation payments for foregone income, e.g. through agri-environmental schemes, may be required in order to improve farmers' acceptance for application of selective herbicide treatments on arable fields, with the objective of preserving rare species and species with important ecological benefits.

\section{References}

AEBISCHER NJ (1997) Effects of cropping practices on declining farmland birds during the breeding season. Proceedings of the Brighton Crop Protection Conference - Weeds, Brighton, UK.

Asteraki EJ, Hart BJ, IngS TC \& MANLEy WJ (2004) Factors influencing the plant and invertebrate diversity of arable field margins. Agriculture, Ecosystems and Environment 102, 219-231.

Chamberlain De, Fuller RJ, Bunce RGH, Duckworth JC \& Shrubb M (2000) Changes in the abundance of farmland birds in relation to the timing of agricultural intensification in England and Wales. Journal of Applied Ecology 37, 771-788.

DAVIES, K. (2003) Winter wheat and barley: the integrated management of broad-leaved weeds and meadow-grass. Scottish Agricultural College (SAC) Technical Note 540

DE SNOO GR (1995) Unsprayed field margins: implications for environment, biodiversity and agricultural practice. Unpublished $\mathrm{PhD}$ Thesis, Leiden University, The Netherlands.

DE SNOO GR \& LUTTIK R (2004) Availability of pesticide-treated seed on arable fields. Pest Management Science 60, 501-506.

DEUTSCHER WETTERDIENST 2008: www.dwd.de

Derksen DA, Thomas AG, LAFOnd GP, Loeppky HA \& SwANTON CJ (1995) Impact of post-emergence herbicides on weed community diversity within conservationtillage systems. Weed Research 35, 311-320.

FitzGerALD JD \& SOLOMON MG (2004) Can flowering plants enhance numbers of beneficial arthropods in UK apple and pear orchards? Biocontrol Science and Technology 14, 291 - 300. 
FREE JB (1993) Insect pollination of crops. London, UK: Academic Press.

FreI G \& MANHART C (1992) Nützlinge und Schädlinge an künstlich angelegten Ackerkrautstreifen in Getreidefeldern. W. Nentwig \& H.-M. Poehling (Eds.), Agrarökologie 4 (Vol. 4). Bern, Switzerland and Stuttgart, Germany: Hauptverlag.

HÅKANSSON S (2003) Weeds and weed management on arable land: an ecological approach. Oxon, UK: CABI Publishing.

Hawes C, Haughton aj, Osborne Jl, Roy DB, Clark SJ, Perry Jn, Rothery P, Bohan DA, Brooks DR, Champion GT, Dewar AM, Heard MS, Woiwod IP, Daniels RE, Young MW, Parish AM, Scott RJ, Firbank LG \& Squire GR (2003) Responses of plants and invertebrate trophic groups to contrasting herbicide regimes in the Farm Scale Evaluations of genetically modified herbicide-tolerant crops. Philosophical Transactions of the Royal Society B 358, 1899-1913.

HyvöNEN T, Ketoja E \& SALONEN J (2003) Changes in the abundance of weeds in spring cereal fields in Finland. Weed Research 43, 348-356.

Jones NE, SMITH B, CooK SK \& Holland JM (2007) Manipulate within crop agronomy to increase biodiversity: Integrated crop management strategies In: The SAFFIE Project Report, ADAS (pp. 108-267). Boxworth, UK.

JONES NE \& SMITH BM (2007) Effects of selective herbicide treatments, row width and spring cultivation on weed and arthropod communities in winter wheat. Aspects of Applied Biology 81, 39-46.

Jongepierova I, Mitchley J \& TZANopoulos J (2007) A field experiment to recreate species rich hay meadows using regional seed mixtures. Biological Conservation 139, 297-305.

KUDSK P \& StREIBIG JC (2003) Herbicides - a two-edged sword. Weed Research 43, 90102.

LUTMAN PJW (2005) Sustainable weed management: development of techniques to balance biodiversity benefits with retention of yield. Research Project Final Report, UK Government.

LutMan PJW, Cussans GW, WRight KJ, WiLSON BJ, MCN Wright G \& LAWSON HM (2002) The persistence of seeds of 16 weed species over six years in two arable fields. Weed Research 42, 231-241.

Maccherini S, Marignani M, CASTAgnini P \& VAN DEN Brink PJ (2007) Multivariate analysis of the response of overgrown semi-natural calcareous grasslands to restorative shrub cutting. Basic and Applied Ecology 8, 332-342. 
Marshall EJP, Brown VK, Boatman ND, Lutman PJW, Squire GR \& Ward LK (2003) The role of weeds in supporting biological diversity within crop fields. Weed Research 43, 77-89.

MARSHALl EJP \& MOONEN AC (2002) Field margins in northern Europe: their functions and interactions with agriculture. Agriculture, Ecosystems and Environment 89, $5-21$.

PerJu T \& MOldovan I (1991) Entomofauna of Centaurea species with a view to biological control. Buletinul Institutului Agronomic Cluj Napoca. Seria Agricultura si Horticultura 45, 73 - 84.

Pywell RF, Warman EA, Sparks TH, Greatorex-Davis JN, Walker KJ, Meek WR, CARvell C, PETIT S \& Firbank LG (2004) Assessing habitat quality for butterflies on intensively managed farmland. Biological Conservation 118, 313-325.

R Development Core Team (2007) R: A language and environment for statistical computing. R Foundation for Statistical Computing. ISBN 3-900051-07-0, URL http://www.R-project.org.

RUSSELL EP (1989) Enemies Hypothesis: A review of the effect of vegetational diversity on predatory insects and parasitoids. Journal of Environmental Entomology 18, 590599

Smith BM, Holland JM, Jones NE, Moreby S, Morris AJ \& Southway SE (2009) Enhancing invertebrate food resources for skylarks in cereal ecosystems: how useful are in-crop agri-environment scheme management options? Journal of Applied Ecology 46, 692-702.

StORKEY J \& WeStBuRY DB (2007) Managing arable weeds for biodiversity. Pest Management Science 63, 517-523.

TER BRAAK CJF \& SMILAUER P (2002) CANOCO Reference Manual and CanoDraw for Windows User's Guide: Software for Canonical Community Ordination (version 4.5). Microcomputer Power. Ithaca, New York.

Torra J, GonZalez-Andujar JT \& Recasens J (2008) Modelling the population dynamics of Papaver rhoeas under various weed management systems in a Mediterranean climate. Weed Research 48, 136-146.

VAN DEN BRINK PJ \& TER BRAAK CJF (1999) Principal response curves: Analysis of timedependent multivariate responses of biological community to stress. Environmental Toxicology and Chemistry 18, 138-148. 
WeISS E \& STETTMER C (1991) Unkräuter in der Agrarlandschaft locken blütenbesuchende Nutzinsekten an. Bern, Switzerland and Stuttgart, Germany: Hauptverlag.

Westbury DB, WoOdcock BA, Harris SJ, Brown VK \& PotTs SG (2008) The effects of seed mix and management on the abundance of desirable and pernicious unsown species in arable buffer strip communities. Weed Research 48, 113-123.

WiLSON PJ (2007) The Status of Centaurea cyanus in Britain. Unpublished. 


\section{CHAPTER}

\section{4}

Implementing conservation auctions to pay farmers for delivering environmental services 


\begin{abstract}
There is a pressing need to develop and implement incentive-based mechanisms for conservation policy to counteract the ongoing loss of biodiversity and associated environmental services in human-dominated agricultural landscapes. Payments for environmental services (PES) schemes have recently emerged as a promising instrument for creating economic incentives to farmers for the conservation of biodiversity. Here, we developed and implemented a regionally-scaled incentive-based PES scheme targeted at the conservation of arable plant diversity. Incentive-based approaches such as PES schemes by means of conservation auctions have increasingly been proposed to achieve biodiversity conservation for a limited predetermined budget more cost-effective than fixed-priced payments. Against the background of PES scheme design and implementation, we particularly addressed two critical key characteristics. Firstly, we addressed the characteristic of additionality by assessing whether the implemented PES scheme resulted in an increase in biodiversity provision. As the cost-effectiveness of a conservation auction increases if payments compensate just farmers' opportunity costs of contract compliance, we secondly tested whether bid prices of participating farmers were closely related to their actual opportunity costs. By accomplishing additionality, our scheme proved to be highly effective in ensuring environmental services delivery through enhancing arable plant diversity. In contrast, the potential of the proposed conservation auction to raise cost-effectiveness has to be questioned as bid prices submitted in our PES scheme exceeded individual farmers' opportunity costs enormously. Our study illustrates potentials and pitfalls associated with the implementation of a PES scheme and therewith contributes to an improved understanding of incentive-based mechanism for both policymakers and practitioners involved in PES scheme design and implementation.
\end{abstract}

Keywords: arable plants species, biodiversity, conservation performance payments, incentive-based instruments, opportunity costs 


\section{Introduction}

The lack of market prices for most environmental services provided by biodiversity is one of the driving forces behind their current decline (Ten Brink et al., 2009). To counteract this market deficiency, incentive- or market-based mechanisms (Jack et al., 2008) are increasingly advocated as instruments for achieving conservation goals in agricultural landscapes and to compensate farmers for the provision of environmental services (Kroeger \& Casey, 2007). Against this background, payments for environmental services (PES) have recently emerged as a promising policy instrument for creating economic incentives for the provision of environmental services in both developed and developing countries (Wunder, 2007; Jack et al., 2008). Incentive-based PES schemes generally involve a voluntary agreement between at least one provider (farmer) and one recipient (paying conservation agency) over a well-defined environmental service. A further key criterion of PES schemes is that payments to farmers are fully dependent on service provision. PES that are conditional on a measurable and well-defined environmental service are also referred to as performance payments (Zabel \& Holm-Müller, 2008), direct payments for conservation (Ferraro, 2001; Ferraro \& Kiss, 2002) or payment by results (Klimek et al., 2008).

To purchase environmental services from farmers within a PES approach, auction contracts for conservation by means of competitive biddings have been suggested to deliver environmental services for a fixed financial budget more cost-effective compared with uniform payments (Naidoo et al., 2006; Schilizzi \& Latacz-Lohmann, 2007). The potential benefit of such an approach is the possibility of adjusting conservation contract payments to the individual compliance costs that farmers face in order to meet obligatory scheme requirements. These compliance costs mainly comprise opportunity costs that are usually unknown to the paying conservation agency, a phenomenon referred to as information asymmetry (Schilizzi \& Latacz-Lohmann, 2007). In this context, opportunity costs of conservation are those associated with the benefit foregone from alternative land use activities (Wunder et al., 2008). In farming systems, opportunity costs vary spatially with the considered production system and region but they are, however, crucial for the willingness to accept a conservation contract (Jack et al., 2009). Within an auction procedure, each farmer submits a sealed bid with an associated payment he is willing to accept for the provision of a predefined environmental service. By creating a competitive temporary market, conservation auctions act as a cost-revealing mechanism and have been 
suggested to create decentralised incentives to farmers to offer bids close to their true opportunity costs (Connor et al., 2008). However, the potential for a conservation auction to raise cost-effectiveness depends on the heterogeneity of farmers' opportunity costs and on the degree to which bid prices actually reflect these opportunity costs (Stoneham et al., 2003).

Here, we implemented an incentive-based PES scheme by means of an auction mechanism to create incentives to farmers to provide arable plant diversity on their managed land. Arable plant diversity in farming systems has been found to support important environmental services such as pollination activity (Carreck \& Williams, 2002) and biological pest control (Altieri \& Letourneau, 1982). However, in the context of European agri-environment schemes (AES), the conservation of in-field arable plant diversity has recently received limited attention. Given the current rapid decline in arable biodiversity and associated environmental services, payment schemes that offer appropriate economic incentives to farmers to conserve biodiversity are therefore urgently needed to complement existing AES which are mainly based on command-and-control regulations.

Following, we will present the conceptual framework and implementation of a PES scheme in arable cropping systems in Germany. In order to contribute to the current debate on PES scheme effectiveness, we particularly address two critical key characteristics related to PES scheme design and implementation: Firstly, we addressed the characteristic of additionality (Wunder et al., 2008) by assessing whether the implemented PES scheme resulted in an increase in biodiversity provision. As the cost-effectiveness of a conservation auction increases if payments compensate just farmers' opportunity costs of contract compliance (Ferraro, 2008), we secondly tested whether bid prices of participating farmers were closely related to their actual opportunity costs. To our knowledge, both the question of whether PES schemes achieve additionality in service provision and the relation between submitted bid prices and individual opportunity costs of farmers within a conservation auction have rarely been addressed and evaluated in an operational PES scheme. Practical experience with and research on these two major issues contributes to an improved understanding of incentive-based mechanism for both policymakers and practitioners involved in PES scheme design and implementation. 


\section{Design and implementation of the PES scheme}

The PES scheme was set up in the administrative district of Northeim in Lower Saxony, Germany, and was based on a conceptual framework for PES schemes that was previously established for biodiversity conservation in managed grasslands (Klimek et al., 2008). Before the implementation of the scheme, regional stakeholders from government agencies, nature conservation and farmers' groups were explicitly involved through a participatory process (Gerowitt et al., 2003; Klimek et al., 2008). In cooperation with natural and social scientists that were in charge of the general administration of the scheme, the regional stakeholders defined and expressed the demand for environmental services. Moreover, they allocated the available budget that was gathered by third-party funding. As arable plant diversity in German conventional farming systems has become increasingly scarce and valuable (Gerowitt et al., 2003), the regional stakeholders decided to allocate the available budget towards the conservation of arable plant diversity on conventionally-managed fields in the project region. Within the scheme, farmers received payments only if a conservation threshold of ten different arable plant species per arable field was achieved. This threshold was defined by the regional stakeholders based on their expert knowledge and was underpinned by scientific studies on arable plant species number in the project region (Ulber et al., 2009). To allow for control of highly competitive grass species on the fields, thresholds referred only to dicotyledonous arable species. For simplicity, we will refer to the defined threshold of arable plant diversity as an environmental service.

We performed two consecutive discriminative-price auctions with a sealed-bid approach and a fixed total budget of 50,000 Euro. In advance to the first auction, information sessions were held in the project region in order to improve farmers' understanding of the demand for environmental services and the auction procedure. Although farmers were informed about the general scheme requirements, no help on bid price calculation was provided. Within each auction, farmers submitted a sealed bid with a corresponding price per hectare for the delivery of environmental services on their fields. Bid prices were than accepted from the lowest bid upwards until the budget was exhausted. Farmers received the payment stated in their accepted bid only if the defined performance threshold was passed. However, penalties for non-compliance with statuary requirements were not applied. 
In the first auction, 12 farmers submitted a total of 26 bids (Table 4.1). These bids comprised a total area of 43 ha and bid prices summed up to 23,766 Euro. Mean bid prices ranged from 100-750 Euro per hectare with an average bid price of 477.8 Euro per hectare. As the available budget was not exhausted, all bids were accepted. Before the second bidding round, no announcement of height of winning bids in the first bidding round was made.

Table 4.1 Summary statistics of the submitted and accepted bids as well as compliance with the requirements in the two consecutive conservation auctions for arable plant diversity conducted in 2007/08 (1st auction) and 2008/09 (2nd auction).

\begin{tabular}{lrr}
\hline & 1st auction & 2nd auction \\
\hline Submitted bids & 12 & \\
No. of farms & 26 & 11 \\
No. of sites & 43.1 & 48 \\
Total area (ha) & 100 & 94.1 \\
Min bid price (€/ha) & 750 & 250 \\
Max bid price (€/ha) & 477.76 & 670 \\
Mean bid price (€/ha) & 23766 & 422.00 \\
Sum of bid prices (€) & 50000 & 22440 \\
Available budget (€) & & \\
Accepted bids & 12 & 7 \\
No. of farms & 26 & 30 \\
No. of sites & 43.1 & 47.6 \\
Total area (ha) & 100 & 250 \\
Min bid price (€/ha) & 750 & 549 \\
Max bid price (€/ha) & 477.76 & 335.74 \\
Mean bid price (€/ha) & 23766 & 22440 \\
Sum of bid prices (€) & & \\
Non-compliance with requirements & 72.1 & \\
No. of sites & & \\
Total area (ha) & & \\
\hline
\end{tabular}

In the second bidding round, a total of 11 farmers submitted 48 bids. These bids summed up to 47,516 Euro and comprised an area of 94 ha. The mean bid price was 422 Euro per hectare. In the second bidding round, only 36 bids could be contracted as the sum of bid prices exceeded the available budget (Table 4.1). 
To verify whether the contracted farmers complied with the statuary requirements, plots of $100 \mathrm{~m}^{2}$ located in the field centre were monitored at the end of the contract period. Monitoring of participating fields revealed that $73 \%$ and $90 \%$ of the bids were successful in achieving the defined service threshold in the first and second bidding round, respectively.

\section{Evaluating the performance of the PES scheme}

In order to evaluate the PES scheme, we used a paired approach for a subset of fields participating in the first auction. Field pairs of winter wheat were composed including 14 field subscribed to the PES scheme (PES fields) and 14 conventionally managed field from the same farmer used as a 'business-as-usual' control (reference fields). Reference fields were identified and matched to PES fields after acceptance of bids. Fields within a pair were located close to each other to minimise differences in shape, size, soil and landscape context (Kleijn et al., 2006). We tested for additionality in environmental service provision by quantifying the difference in arable plant species number between paired PES and reference fields. At each field, we assessed plant species number in the $100 \mathrm{~m}^{2}$ monitoring plots. Fields within one pair were sampled for plant species richness on the same day.

To test the potential for the PES scheme to be cost-effective, we estimated farmers'

opportunity costs for participating in the scheme. These private opportunity costs include the costs of reduced crop production, costs related to potential management changes as well as any offsetting benefits caused by e.g. reduced input of pesticides and fertilisers (Rolfe et al., 2009). For the calculation of opportunity costs, management data of paired fields were retrieved from farmers by standardised face-to-face interviews. Based on those management data, we first calculated gross margin per hectare for each field, defined as gross financial revenue minus variable costs per hectare (Sinden, 2004). Variable costs for crop production include costs for crop seeds, fertilisers, plant protection products (herbicides, fungicides and insecticides), machinery and cleaning and drying of harvested grain. However, no information on individual costs of harvest, cleaning and drying of winter wheat grain could be gained in the course of the interviews. Standard values were therefore used for the reference fields (Ktbl, 2009). For PES fields, increased costs for drying and storage costs were assumed due to higher arable plant abundance. Similarly, $20 \%$ additional costs for impeded harvest operations were considered for PES fields. After 
assessing the gross margin of each field, we calculated opportunity costs for each pair as the difference in gross margin between PES and reference field.

\section{Does the PES scheme achieve additionality in service provision?}

In the first auction, a total of 45 and 26 different arable plant species were respectively detected on the surveyed paired PES and reference fields. Compared to reference fields, mean plant species number was almost three times higher on PES fields (Wilcoxon ranked test; $p<0.0001 ;$ Fig. 4.1).

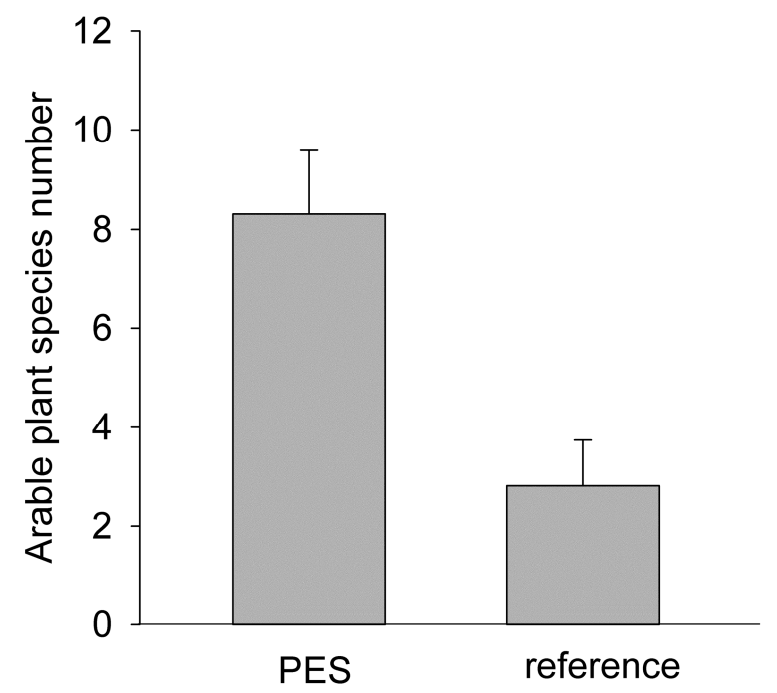

Figure 4.1 Number of arable plant species on paired payment for environmental services (PES) and reference fields. Means + SEM are shown.

Interviews with farmers revealed that this difference was mainly attributable to lower fertiliser and reduced input of broad-spectrum herbicides on PES fields. Our results therefore clearly demonstrate that management changes adjusted to the delivery of environmental services in arable systems can result in an immediate enhancement of environmental service supply. However, the time-scale of our PES scheme was limited to one year conservation contracts. This is likely to threaten the long-term delivery of environmental services as farmers might return to their previous conventional practice after expiration of the scheme (Bräuer et al., 2006). However, from an ecological point of view, a time-scale of one year seems sufficient as plants under the alternative adopted management practices are allowed to reproduce and therefore sustain in the soil seed bank of the fields. Importantly, interviews with participating farmers revealed that especially the short time-scale of the conducted scheme increased its attractiveness. Although our scheme 
clearly achieved additionality in service provision, we did not account for a potential difference in the ecological quality of the environmental services delivered by farmers. For example, our PES scheme did not explicitly account for the presence of threatened arable plant species (Aavik \& Liiraa, 2009). Out of all species encountered during on-the-spot monitoring, only two species were listed in the Red List of Threatened Species of Lower Saxony (Garve, 2004). Hence, most species encountered on PES fields belonged to a set of common species that can be found in a wide range of arable habitats (Heard et al., 2003). In this context, conservation thresholds for environmental services that are not only defined by a fixed threshold of arable plant species but by a certain number of threatened arable plant species might have provided a more targeted approach for the conservation of threatened plant species.

\section{Do bid prices in a conservation auction reflect farmers' opportunity costs?}

Estimation of farmers' opportunity costs revealed that farmers faced heterogeneous costs for the delivery of environmental services. Opportunity costs per field ranged from -12.5 to 543.6 Euro per hectare with an average of 190.1 Euro (Table 4.2).

This high variation indicates that farmers adopted different alternative management techniques to deliver the defined environmental service. Opportunity costs were mainly associated with reduced crop yields on PES fields which accounted for $65 \%$ of overall opportunity costs and also differed widely among farmers. Average differences in crop revenue between PES and reference fields amounted to 121.6 Euro per hectare which is in accordance to results of Mettepenningen et al. (2009) indicating an average decrease in crop revenue of 176.8 Euro per hectare for participation in European arable agrienvironment schemes. In our scheme, variable costs, as another component of opportunity costs, differed to a lower extent between PES and reference fields. Mean variable costs were higher on PES fields and made up $28 \%$ of the total opportunity costs. On the one hand, farmers were able to reduce costs for fertilisers on PES field which might have partially offset the increase in opportunity costs caused by lower yields. On the other hand, costs for plant protection products were higher on fields participating in the scheme. Although this was partly due to different herbicide products used on PES compared to reference fields, farmers did not tend to reduce fungicide and insecticide input on PES fields. Contrary, a study measuring opportunity costs of farmers participating in European AES showed that application of AES resulted in 4.1-9.9\% cost savings for manure, 
fertiliser and pesticide costs (Mettepenningen et al., 2009). In our PES scheme, opportunity costs arising from scheme participation therefore seems to be strongly influenced by individual site- and management-specific conditions.

Table 4.2 Opportunity costs (OP costs: difference $(\Delta)$ in gross margin $(\mathrm{GM})$ ), difference $(\Delta)$ in crop revenue, variable costs, plant protection products (PPP) and fertiliser between payment for environmental services (PES) and reference (REF) winter wheat fields as well as bid prices submitted for PES fields. Mean, range of values and standard error of mean (SEM) are given.

\begin{tabular}{ccc}
\hline & \multicolumn{1}{c}{ Mean (range) } & SEM \\
\hline OP costs ( $\triangle$ GM; PES - REF; €/ha) & $-190.1(-543.6-12.5)$ & 31.7 \\
$\Delta$ crop revenue (PES - REF ; €/ha) & $-121.6(-505.2-21.9)$ & 31.2 \\
$\Delta$ var. costs (PES - REF; €/ha) & $53.5(-235.5-184.9)$ & 29.8 \\
$\Delta$ PPP (PES - REF; €/ha) & $10.7(-104.2-85.8)$ & 13.7 \\
$\Delta$ fertiliser (PES - REF; $€ / h a)$ & $-9.8(-78.4-170.9)$ & 15.1 \\
Bid price $(€ / h a))$ & $586.2(375.0-750.0)$ & 25.1 \\
\hline
\end{tabular}

Most importantly, farmers ` bid prices submitted in the first auction generally exceeded the estimated opportunity costs (Table 4.2). In addition, there was no significant relationship between opportunity costs and bid prices $(r=0.03, p=0.9$; Fig. 4.2). Hence, bid prices in our PES conservation auctions seem to be determined by other socioeconomic factors than simply foregone profits.

Above all, farmers might have faced difficulties calculating their bids prices. Although bidders in conservation auctions are assumed to have good knowledge about their opportunity costs and consequently use this information to calculate their bids (LataczLohmann \& Van Der Hamsvoort, 1997; Stoneham et al., 2003), interviews with farmers participating in our PES scheme revealed that they had only limited information about potential opportunity costs arising from scheme participation. Moreover, farmers stated that the auction process was unfamiliar to them and they were therefore hardly able to calculate a reasonable bid price for the provision of environmental service.

Additionally, risk perception of farmers and transaction costs might have been taken into consideration for bid price calculation. It is known that the delivery of environmental services in PES schemes is not only affected by farm management but also by 
environmental factors outside the direct control of the farmer such as weather conditions (Rollett et al., 2008). Farmers might also have demanded a risk premium on top of their opportunity costs in order to compensate for unexpected long-term foregone income (Wätzold \& Schwerdtner, 2005); e.g. caused by increased costs for control of higher arable plant infestations in subsequent years. In addition, farmers' perception of rising crop market prices during the time of the PES scheme implementation may additionally have contributed to a calculation of relatively high bids prices.

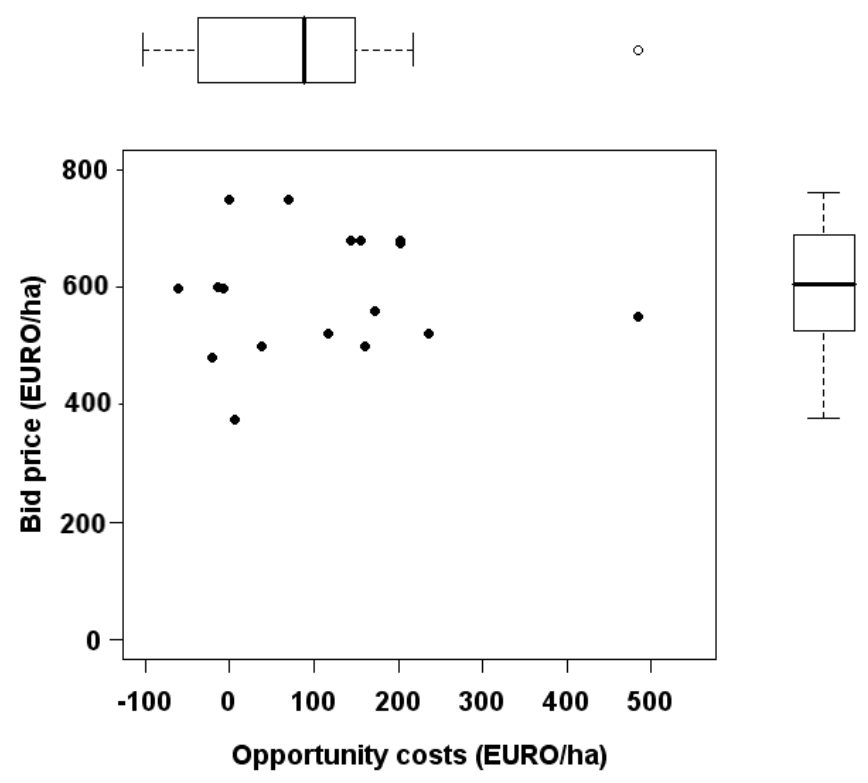

Figure 4.2 Opportunity costs and submitted bid prices of farmers participating in the payment for environmental services (PES) scheme.

Besides risk perception of farmers, there is evidence that auctions for environmental services might result in substantial transaction costs not only for the scheme implementation and monitoring but also for the participating farmers (Wätzold \& Schwerdtner, 2005). According to Mettepenningen et al. (2009), transaction costs include ex ante search and information costs, decision-making costs, costs for hiring of advice e.g. consultants and ex post monitoring costs. In European AES, up to $20 \%$ of the payment is added for transaction costs (Rollett et al., 2008). This corresponds to findings of a study on ten European AES in which mean transaction costs for individual farmers were about 40 Euro per year (including wages) and accounted for $14 \%$ of total farmers' participating costs (Mettepenningen et al., 2009). As decision-making costs for bid calculation have been found to vary according to the management changes required to 
obtain a demanded environmental service (Windle \& Rolfe, 2008), it is likely that farmers included some costs for the individual planning of the most appropriate management measure within their bids.

Finally, farmers may further aim for certain information rents in addition to risk premiums and transaction costs. It has been suggested that bids in conservation auctions might always include some information rent (Rolfe et al., 2009). This is supported by evidence from the U.S. Conservation Reserve Program in which estimated information rents constituted 10$40 \%$ of the program's rental payout (Kirwan et al., 2005). However, paying information rents might be required to increase farmers' incentive to enrol in a PES scheme (Kirwan et al., 2005; Rolfe et al., 2009).

The lack of correspondence between opportunity costs and bid prices as found in our PES scheme might further be caused by the relatively low participation of farmers. It is known from competitive auction theory that, in order to be cost-effective, competitive auctions require a large pool of bidders to induce competitive pressure (Ferraro, 2008). As our PES scheme was targeted at a defined region, it addressed only a limited number of farmers. In our first bidding round, competition was low and the cost-effective advantage of competitive auctions could therefore not be fully exploited. However, as the number of submitted bids was significantly higher in the second bidding round, competition between bids occurred and bids had to be rejected. As a consequence, average accepted bid prices were lower in the second auction round (Table 4.1). Our results therefore indicate that competition in conservation auctions has an enormous impact on accepted bid prices and related cost-effectiveness. In this context, the setting of a reserve price, as an upper limit of the amount the conservation agency is willing to pay for a unit of an environmental service (Stoneham et al., 2003), is believed to overcome the problem of reduced competition when the number of bidders is low. As over-priced bids are more likely to exceed the reserve price, the setting of such a reserve price encourages farmers to bid closer to their costs especially when competition is thin (Windle \& Rolfe, 2008).

\section{Conclusion}

There is a pressing need to develop and implement incentive-based policy instruments to maintain and enhance biodiversity and associated environmental services in humandominated agricultural landscapes (Kroeger \& Casey, 2007; Jack et al., 2008). Our proposed and implemented PES scheme provided farmers with financial incentives to 
deliver environmental services in addition to the production of food and fibre (Klimek et al. 2008). By accomplishing additionality, our scheme was highly effective in ensuring environmental services delivery. Moreover, the incentive-based PES schemes provided farmers with maximum flexibility with respect to innovative conservation management practise to deliver a desired level of environmental services. However, our scheme did not intent to substitute command-and-control measures within existing European AES schemes but was rather aimed at complementing them by compensating farmers directly for undertaking management changes that increase the delivery of environmental services in arable systems.

However, as bid prices submitted in our PES scheme exceeded estimated farmers' opportunity costs enormously, the potential of the proposed conservation auction to raise cost-effectiveness has to be questioned. We have argued that bid prices were strongly influenced by factors other than opportunity costs such as perception of productions risk, transaction costs or farmers' profit expectation (Ferraro, 2008; Jack et al., 2008; Zabel \& Roe, 2009). As farmers facing competition are less likely to 'overbid' their real opportunity costs (Latacz-Lohmann \& Schilizzi, 2007; Zabel \& Roe, 2009), the number of submitted bids might have been not large enough to allow for sufficient competition. Although several studies have demonstrated that conservation auctions can reduce informational rents by acting as a cost-revealing mechanism, especially when multiple bidding rounds are employed (Windle \& Rolfe, 2008; Jack et al., 2009), in-depth knowledge on the relative importance of factors influencing farmers' bidding behaviour and willingness to participate in PES schemes is still limited. Additional rigorous research, objective monitoring and evaluation of pilot PES schemes is therefore required to determine whether conservation auctions facilitate the cost-effective allocation of environmental service provision.

\section{Acknowledgements}

We thank all participating farmers for their unrestricted willingness to answer numberless questions and the regional stakeholders for their participation. The authors are grateful for the support provided by the Deutsche Bundesstiftung Umwelt and the German Federal Ministry of Education and Research. 


\section{References}

AAVIK T \& LIIRAA J (2009) Agrotolerant and high nature-value species. Plant biodiversity indicator groups in agroecosystems. Ecological Indicators 9, 892-901.

ALTIERI MA \& LETOURNEAU DK (1982) Vegetation management and biological control in agroecosystems. Crop Protection 1, 405-430.

BräUer I, Müssner R, Marsden K, OOsterhuis F, Rayment M, Miller C \& DoDOKOVÁ A (2006) The use of market incentives to preserve biodiversity. A framework for the European Commission.

CARRECK NL \& WILLIAMS IH (2002) Food for insect pollinators on farmland: insect visits to flowers of annual seed mixtures. Journal of Insect Conservation 6, 13-23.

CONNOR JD, WARD JR \& BRYAN B (2008) Exploring the cost effectiveness of land conservation auctions and payment policies. The Australian Journal of Agricultural and Resource Economics 51, 303-319.

FERRARO PJ (2001) Global habitat protection: Limitations of development interventions and a role for conservation performance payments. Conservation Biology 15, 9901000 .

FERRARO PJ (2008) Asymmetric information and contract design for payments for environmental services. Ecological Economics 65, 810-821.

FERRARO PJ \& KISS A (2002) Direct payments to conserve biodiversity. Science 298, 1718-1719.

GARVE E (2004) Rote Liste und Florenliste der Farn- und Blütenpflanzen in Niedersachsen und Bremen. Informationsdienst Naturschutz Niedersachsen 1, 1-76.

Gerowitt B, BertKe E, Hespelt SK \& Tute C (2003) Towards multifunctional agriculture - weeds as ecological goods? Weed Research 43, 227-235.

Heard MS, Hawes C, Champion GT, Clark SJ, Firbank lG, Haughton AJ, Parish DMB, Perry JN, Rothery P, ScotT RJ, SKellern MP, SQuire GR \& Hill MO (2003) Weeds in fields with contrasting conventional and genetically modified herbicide-tolerant crops. II. Effect on individual species. Philosophical Transactions of the Royal Society London B 358, 1833-1846.

JACK BK, Kouskya C \& SIMS KRE (2008) Designing payments for ecosystem services: Lessons from previous experience with incentive-based mechanisms. PNAS 105, 9465-9470. 
JACK BK, LEIMONA B \& FERRARO PJ (2009) A revealed preference approach to estimating supply curves for ecosystem cervices: Use of auctions to set payments for soil erosion control in Indonesia. Conservation Biology 23, 359-367.

KIRWAN B, LUBOWSKI RN \& ROBERTS MJ (2005) How cost-effective are land-retirement auctions? Estimating the difference between payments and willingness to accept in the Conservation Reserve Program. American Journal of Agricultural Economics 87, 1239-1247.

Kleijn D, Baquero Ra, Clough Y, Díaz M, De Esteban J, Fernández F, Gabriel D, Herzog F, Holzschuh A, Jóhl R, Knop E, Kruess A, Marshall EJP, StefFanDewenter I, Tscharntke T, Verhulst J, West TM \& Yela JL (2006) Mixed biodiversity benefits of agri-environment schemes in five European countries. Ecology Letters 9, 243-254.

Klimek S, Richter gen. Kemmermann A, Steinmann H-H, Freese J \& Isselstein J (2008) Rewarding farmers for delivering vascular plant diversity in managed grasslands: A transdisciplinary case-study approach. Biological Conservation 141, 2888-2897.

Kroeger T \& CASEY F (2007) An assessment of market-based approaches to providing ecosystem services on agricultural lands. Ecological Economics 64, 321-332.

KTBL; Kuratorium für Technik und Bauwesen in der Landwirtschaft e.V. (2009) Faustzahlen für die Landwirtschaft 14 ed. Darmstadt, Germany.

LATACZ-LOHMANN U \& SCHILIZZI S (2007) Quantifying the benefits of conservation auctions. EuroChoices 6, 32-39.

LATACZ-LOHMANN U \& VAN DER HAMSVOORT C (1997) Auctioning conservation contracts: A theoretical analysis and an application. American Journal of Agricultural Economics 79, 407-418.

Mettepenningen E, Verspecht A \& van Huylenbroeck G (2009) Measuring private transaction costs of European agri-environmental schemes. Journal of Environmental Planning and Management 52, 649-667.

Naidoo R, Balmford A, Ferraro PJ, Polasky S, Ricketts TH \& Rouget M (2006) Integrating economic costs into conservation planning. TRENDS in Ecology and Evolution 21, 681-687.

Rolfe J, Windle J \& McCosker J (2009) Testing and implementing the use of multiple bidding rounds in conservation auctions: A case study application. Canadian Journal of Agricultural Economics 57, 287-303. 
Rollett A, Haines-Young R, Potschin M \& Kumar P (2008) Delivering environmental services through agri-environment programmes: a scoping study. Land Use Policy Group. The UK statutory conservation, countryside and environment agencies.

SCHILIZZI S \& LATACZ-LOHMANN U (2007) Assessing the performance of conservation auctions: An experimental study. Land Economics 83, 497-515.

SINDEN JA (2004) Estimating the costs of biodiversity protection in the Brigalow belt, New South Wales. Journal of Environmental Management 70, 351-362.

Stoneham G, Chaudhri V, Ha A \& Strappazzon L (2003) Auctions for conservation contracts: an empirical examination of Victoria's BushTender trial. The Australian Journal of Agricultural and Resource Economics 47, 477-500.

TEN Brink P, BerghöFer A, Schröter-SchlaAck C, Sukhdev P, VAKrou A, White S \& WiTTMER H (2009) TEEB-The Economics of Ecosystems and Biodiversity for National and International Policy Makers. Summary: Responding to the Value of Nature.

Ulber L, Steinmann H-H, KlimeK S \& Isselstein J (2009) An on-farm approach to investigate the impact of diversified crop rotations on weed species richness and composition in winter wheat. Weed Research 49, 534 - 543.

WÄTZOLD F \& SCHWERDTNER K (2005) Why be wasteful when preserving a valuable resource? A review article on the cost-effectiveness of European biodiversity conservation policy. Biological Conservation 123, 327-338.

WINDLE J \& ROLFE J (2008) Exploring the efficiencies of using competitive tenders over fixed price grants to protect biodiversity in Australian rangelands. Land Use Policy 25, 388-398.

WUNDER S (2007) The efficiency of payments for environmental services in tropical conservation. Conservation Biology 21, 48-58.

Wunder S, Engel S \& Pagiola S (2008) Taking stock: A comparative analysis of payments for environmental services programs in developed and developing countries. Ecological Economics 65, 834-852.

ZABEL A \& Holm-MüLleR K (2008) Conservation performance payments for carnivore conservation in Sweden. Conservation Biology 22, 247-251.

Zabel A \& RoE B (2009) Optimal design of pro-conservation incentives. Ecological Economics 69, 126-134. 


\section{CHAPTER}

5

Discussion \& Conclusion 


\section{Discussion \& Conclusion}

An increase in the global food demand projected for the future years constitutes a great challenge for the productivity of arable crops and agricultural ecosystems as well as the services they provide to society. New management approaches for ensuring the sustainability of agricultural production and delivery of environmental services will be crucial if the demands of improving yields need to be met (Tilman et al., 2002). Against this background, weed species pose a major threat to arable crop productivity by causing reductions in crop yield and quality and interference with harvesting (Liebman, 2001). The development towards more effective weed control and increased intensity of management techniques has undoubtedly contributed to crop yield increase and efficiency of production. During the last decades, however, these processes have also resulted in a decline of weed species diversity in arable cropping systems (Potts et al., 2010). There is increasing awareness that high weed species diversity might be beneficial by providing a range of beneficial ecological functions and services such as pest control, resource and habitat provision for higher trophic level and nutrient cycling (Norris \& Kogan, 2005).

In temperate cropping systems, the intensity of management can be regarded as the most important driver of weed species diversity. In this context, organic farming offers one route to maintain or restore farmland biodiversity as it has been shown to be associated with increased richness and abundance of weed species (Bengtsson, 2005). Against this, the conflict between the goals of maximising crop productivity and enhancement of weed diversity and agricultural sustainability results in two possible land use options for conventional cropping systems (Makowski et al., 2007; Storkey \& Cussans, 2007). One option is to adopt biodiversity-friendly management practices within the cropped body of the field (land sharing). This approach implies accepting the risk of reduced crop yields caused by increased weed competition. The other option is to conduct intensive crop production in parts of the field and spare other parts by means of set asides, field-margins with sown species mixtures or conservation headlands for biodiversity conservation (land sparing). The success of the land sparing approach, however, is constrained by the fact that the proportion of non-crop farmland is currently being reduced due to a decrease in setaside land and an increase in the production of energy crops (Storkey \& Westbury, 2007). In addition, especially the weed flora found within the crop constitutes an important component of arable biodiversity. Some farmland bird species such as skylarks (Alauda arvensis) avoid field boundaries and are most likely to forage within the centre of the field 
(De Snoo \& Luttik, 2004). This highlights the importance of an integrated in-crop approach for conservation of beneficial and rare weed species within the actual cropped environment.

In chapter 2 of this thesis, the relative importance of crop rotation intensity and weed control treatment for weed species richness and community composition in crops of winter wheat was analysed. In accordance to the underlying assumption, weed species richness responded to overall management and was higher in organic systems. Neither the total number of weed species nor the number of species with beneficial functions differed significantly between conventional diverse and conventional simple crop rotations. In contrast, the negative response of species richness to application of weed control treatment was significant in both conventional rotations but not in the organic one. In conventional crop rotations, the effect of temporal crop diversity on weed species richness therefore seems to be punctuated by the high annual disturbance exerted by herbicide application. This is in accordance to other studies which reported little or no effect of crop rotation on weed communities when the effects of associated management practices such as herbicide application where taken into account (Doucet et al., 1999; Bàrberi \& Lo Cascio, 2001). However, multivariate redundancy analyses (RDA) revealed that crop rotation intensity accounted for a large part of the explained variation in weed species composition. The observation that crop rotation in conventional cropping systems had no significant effect on weed species richness therefore does not negate the importance of incorporating temporal diversity within agricultural management systems. In agreement with the second hypothesis, weed control treatment enhanced winter wheat grain biomass in both conventional but not in the organic rotation. The results therefore show that the maintenance of weed species richness and conservation of species with important beneficial functions requires not only temporal diversification of crop species in the rotation but also an adjustment of weed control strategies.

As demonstrated in chapter 3, selective herbicides for spring application with a narrow spectrum of controlled weed species were found to allow both, retention of beneficial or rare species occurring at moderate densities (Papaver rhoeas and Centaurea cyanus) and successful control of pernicious weed species (Galium aparine) in winter wheat. In agreement with other studies, applications of the active ingredients fluroxypyr and amidosulfuron + iodosulfuron were identified as the most appropriate treatments (Boatman et al., 1999; Lutman, 2005). Multivariate analysis by means of principle response curves 
revealed that herbicide treatments significantly affected weed species composition; the impact of treatment varied according to the target species and experimental sites investigated. The performance of the investigated half dose rates of the herbicides was more variable than that of the recommended field application rate. These findings confirm the hypothesis that narrow-spectrum herbicides offer a possibility of selective in-crop weed management. However, a higher abundance of desirable weed species was associated with considerable reduction of crop yields. The presence of some noxious weed species like Galium aparine and Cirsium arvense may therefore have more serious implications for the choice of herbicides in winter wheat fields than that of beneficial or rare species (Légère et al., 2005). Hence, weed control strategies must be site- as well as year-specific to account for the long-term economic impact of surviving weeds and potential seed return on crop productivity.

Results from the experimental studies in chapter 2 and 3 indicated that weed species diversity could be enhanced in arable cropping systems by means of adaptation of alternative management strategies. Importantly, the examined biodiversity-friendly management strategies were associated with varying reductions in crop yields. In agroecosystems, appropriate economic incentives are therefore required to compensate for financial losses associated with biodiversity-friendly management. In chapter 4, it was demonstrated that the evaluated incentive-based PES scheme created financial incentives for farmers to provide arable plant diversity by means of an auction mechanism. The results confirmed the first hypothesis that the implemented PES successfully ensured environmental services delivery by enhancing weed species diversity on winter wheat fields entered in the scheme. Participating farmers selected different management strategies to increase weed species diversity on their fields. Some farmers reduced or omitted application of herbicides active on broad-leaved species, while other farmers reduced the amount of nitrogen fertilisers or the crop seeding rate. As a consequence, farmers' opportunity costs varied according to changes in the management strategies. Against the underlying expectation, the bid prices farmers submitted in the conservation auction did not reflect the observed heterogeneity in opportunity costs. Moreover, bid prices substantially exceeded the estimated farmers' opportunity costs. Therefore, the potential of the proposed conservation auctions to raise cost-effectiveness is questionable. Presumable, bid prices were strongly influenced by factors other than opportunity costs such as perception of the production risk, transaction costs or farmers' profit expectation (Ferraro, 2008; Jack et al., 2008; Zabel \& Roe, 2009). Although several studies have 
demonstrated that conservation auctions can reduce information rents by acting as a costrevealing mechanism, especially when multiple bidding rounds are employed (Windle \& Rolfe, 2008; Jack et al., 2009), in-depth knowledge on the relative importance of factors influencing farmers' bidding behaviour and willingness to participate in PES schemes is still limited. Additional rigorous research as well as objective monitoring and evaluation of pilot PES schemes is therefore required to determine whether conservation auctions facilitate the cost-effective allocation of environmental service provision.

To conclude, the results of this thesis demonstrate that management of weed species diversity as an important component of farmland biodiversity could be integrated into conventional cropping systems. In the experimental studies conducted in winter wheat, weed control treatments showed the highest impact on weed diversity and community composition. Using the specificity of herbicides allows retaining of desirable species while eliminating only those weed species that require control. However, the investigated management strategies resulted in reduced levels of crop yields and may therefore conflict with farming systems targeted at maximizing economic profit. Certainly, there is still need for a deeper and broader understanding of the ecological benefits that could be received from weeds in return for deliberate management and whether and when these benefits will outweigh negative effects of weeds. Although there is clear evidence that weeds provide a broad spectrum of ecological services, the question whether solely weed species richness or rather the relative abundance of particular beneficial species are essential for the provision of these ecological functions requires further examination. In this context, studies on the relative importance of individual weed species for various taxa at higher trophic levels revealed differences according to the taxa groups considered (Storkey, 2006; Hyvönen \& Huusela-Veistola, 2008). Weed species able to produce numerous seeds (e.g. Chenopodium album, Polygonum aviculare) are especially important for farmland birds whereas other weed species show the highest importance particularly for phytophagous insects. Results from these studies provide a first indication that both the retention of particular weed species and the maintenance of species-rich weed communities consisting of species with different beneficial functions might ensure the successful provision of environmental services.

In this context, the evaluation of the implemented PES scheme showed that farmers were able to identify management strategies suitable for an enhancement of weed species diversity. Incentive-based PES schemes could provide farmers with maximum flexibility 
with respect to innovative conservation management practices in order to deliver a desired level of environmental services. In addition to management practices, environmental factors such as climatic and physical factors, soil properties, landscape complexity and spatial aggregation of conservation areas are important determinants of arable weed species diversity (Lososová et al., 2004; Gabriel et al., 2005; Roschewitz et al., 2005; Tscharntke et al., 2005). The relative importance of such factors in influencing weed communities should therefore also be taken into account for a successful targeting of PES schemes aimed at biodiversity conservation in agricultural landscapes.

\section{References}

BÀRBERI P \& LO CASCIO BL (2001) Long-term tillage and crop rotation effects on weed seedbank size and composition. Weed Research 41, 325-340.

BoAtMAn ND, BEnCE SL \& JARVIS P (1999) Management and costs of conservation headlands on heavy soil. Aspects of Applied Biology 54, 147-154.

DE SNOO GR \& LUTTIK R (2004) Availability of pesticide-treated seed on arable fields. Pest Management Science 60, 501-506.

Doucet C, Weaver SE, Hamill AS \& Zhang J (1999) Separating the effects of crop rotation from weed management on weed density and diversity. Weed Science 47, 729-735.

FERRARO PJ (2008) Asymmetric information and contract design for payments for environmental services. Ecological Economics 65, 810-821.

GABRIEL D, THIES C \& TSCHARNTKE T (2005) Local diversity of arable weeds increases with landscape complexity. Perspectives in Plant Ecology, Evolution and Systematics 7, 85-93.

HYVÖNEN T \& HuUSELA-VEISTOLA E (2008) Arable weeds as indicators of agricultural intensities - A case study from Finland. Biological Conservation 141, 2857-2864.

JACK BK, KousKYa C \& SIMS KRE (2008) Designing payments for ecosystem services: Lessons from previous experience with incentive-based mechanisms. PNAS 105, 9465-9470.

JACK BK, LEIMONA B \& FERRARO PJ (2009) A revealed preference approach to estimating supply curves for ecosystem services: Use of auctions to set payments for soil erosion control in Indonesia. Conservation Biology 23, 359-367. 
LÉGÈre A, Stevenson FC \& BenOIT DL (2005) Diversity and assembly of weed communities: contrasting responses across cropping systems. Weed Research $\mathbf{4 5}$, 303-315.

LiEBMAN M (2001) Weed Management: a need for ecological approaches. M. Liebman, C. L. Mohler \& C. P. Staver (Eds.), Ecological Management of Agricultural Weeds (pp. 532 p). Cambridge, UK: Cambridge University Press.

Lososová Z, M. Chytrý S. Cimalová Z. Kropáč Z. Otýpková P. PyšeK \& TichÝ L (2004) Weed vegetation of arable land in Central Europe: Gradients of diversity and species composition. Journal of Vegetation Science 15, 415-422.

LUTMAN PJW (2005) Sustainable weed management: development of techniques to balance biodiversity benefits with retention of yield. Research Project Final Report, UK Government.

Makowski D, Dore T, Gasquez J \& Munier-Jolain N (2007) Modelling land use strategies to optimise crop production and protection of ecologically important weed species. Weed Research 47, 202-211.

NORRIS RF \& KOGAN M (2005) Ecology of interactions between weeds and arthropds. Annual Review of Entomology 50, 479-503.

PotTs GR, EwAld JA \& AEBISCHER NJ (2010) Long-term changes in the flora of the cereal ecosystem on the Sussex Downs, England, focusing on the years 1968-2005. Journal of Applied Ecology 47, 215-226.

Roschewitz I, Gabriel D, Tscharntke T \& Thies C (2005) The effects of landscape complexity on arable weed species diversity in organic and conventional farming. Journal of Applied Ecology 42, 873-882.

STORKEY J (2006) A functional group approach to the management of UK arable weeds to support biological diversity. Weed Research 46, 513-522.

StORKEY J \& CUSSANS JW (2007) Reconciling the conservation of in-field biodiversity with crop production using a simulation model of weed growth and competition. Agriculture, Ecosystems \& Environment 122, 173-182.

StORKey J \& Westbury DB (2007) Managing arable weeds for biodiversity. Pest Management Science 63, 517-523.

Tilman D, Cassman KG, Matson PA, Naylor R \& Polasky S (2002) Agricultural sustainability and intensive production practices. Nature 418, 671-677. 
Tscharntke T, Klein AM, Kruess A, Steffan-Dewenter I \& Thies C (2005) Landscape perspective on agricultural intensification and biodiversity - ecosystem service management. Ecology Letters 8, 857-874.

WINDLE J \& ROLFE J (2008) Exploring the efficiencies of using competitive tenders over fixed price grants to protect biodiversity in Australian rangelands. Land Use Policy 25, 388-398.

ZABEL A \& RoE B (2009) Optimal design of pro-conservation incentives. Ecological Economics 69, 126-134. 


\section{Summary}

Throughout the last decades, the intensification of farming practices accompanied by simplification of crop rotations, increased nitrogen fertilisation rates and weed control by highly effective herbicides has been associated with a substantial loss of weed species diversity in agricultural systems. However, it has been increasingly recognised that weed species are playing a key role for the maintenance of beneficial ecological functions such as support of higher trophic levels and the provision of environmental services such as pollination and biological control.

This thesis aimed to provide insights into the impacts of crop management strategies on weed species diversity in temperate winter wheat crops and evaluated an implemented payment scheme for environmental services targeted at weed diversity conservation in agricultural landscapes. All experimental and observational studies conducted within the framework of this thesis were carried out in Lower Saxony, Germany.

In a first experimental study, an on-farm approach was used to analyse the effect of crop rotation intensity and weed control treatment on weed communities and crop yield in conventional and organic winter wheat crops. Weed species richness and richness of species with beneficial functions for associated higher trophic levels were significantly greater in the organic crop rotation but did not differ between conventional diverse and conventional simple crop rotations. However, multivariate redundancy analyses (RDA) revealed that crop rotation intensity accounted for a substantial part of the explained variation in weed species composition. Weed control treatment reduced total species richness and number of species with beneficial functions in fields of both conventional rotations but not in the organic fields. Results from this study showed that the maintenance of weed species richness and conservation of species with important ecological functions requires not only temporal diversification of crop species in the rotation but also an adjustment of weed control strategies.

Within a second experimental field study, selective herbicide treatments with a narrow spectrum were identified suitable for controlling pernicious species (Galium aparine) whilst having less effect on less competitive weed species with beneficial functions for higher trophic level (Papaver rhoeas) and rare species of high conservation concern (Centaurea cyanus). Applications of fluroxypyr and amidosulfuron + iodosulfuron were identified as the most appropriate treatments. Multivariate analysis by means of principle response curves (PRC) revealed that herbicide treatments significantly affected weed 
species composition; the impact of treatment, however, varied according to the target species and experimental sites investigated. These results demonstrated that the application of selective herbicides could provide a feasible option for in-crop management of weed diversity. However, it was concluded that weed control strategies have to be site-specific to account for damaging abundances of highly competitive species and associated yield reductions.

The conducted experiments clearly demonstrated links between management strategies targeted at weed diversity conservation and loss of crop yields. Against this background, conservation payment schemes are designed to compensate farmers for any opportunity costs resulting from adaptation of biodiversity-friendly management. Incentive-based conservation schemes such as payments for environmental services (PES) by means of conservation auctions have been suggested to provide biodiversity conservation for a limited predetermined budget more cost-effective than commonly used fixed-priced payments. In a third study, the implementation of a regionally-scaled incentive-based PES scheme targeted at the conservation of arable plant diversity was evaluated. In the scheme, the amount of incentives paid was linked to a measurable environmental service that was a pre-defined threshold of arable weed species. Each farmer participating in the PES conservation auction submitted a sealed bid with an associated payment he was willing to accept for the provision of the pre-defined environmental service. The results demonstrated that the implemented PES was successful in ensuring environmental service delivery by enhancing weed species diversity on participating fields. In contrast, bid prices submitted in our PES scheme exceeded individual farmers' opportunity costs substantially. Hence, bid prices were strongly influenced by factors other than opportunity costs such as perception of productions risk, transaction costs or farmers' profit expectation. The potential of conservation auctions to raise cost-effectiveness therefore requires additional rigorous research, objective monitoring and evaluation of pilot PES schemes.

In conclusion, this thesis provides experimental evidence that management strategies for encouraging the provision of weed diversity can be integrated into conventional cropping systems. However, achieving a balance between the retention of weed species diversity and the maintenance of profitable crop production remains challenging. Therefore, financial incentives provided by PES schemes targeted at biodiversity conservation are important steps towards the goal of designing more economically and ecologically sustainable cropping systems that incorporate the diversity of weed communities. 


\section{Zusammenfassung}

Die Intensivierung der landwirtschaftlichen Produktion anhand von engen Fruchtfolgen, erhöhten Stickstoffdüngerapplikationen und hocheffektiver Unkrautbekämpfung durch Herbizide hat in den letzten Jahrzehnten zu einem Verlust der Unkrautdiversität in ackerbaulichen Systemen geführt. Demgegenüber sind mit einer erhöhten Unkrautdiversität nützliche Funktionen wie die Förderung höherer trophischer Ebenen und die Bereitstellung ökosystemarer Dienstleistungen wie z.B. höherer Bestäubung und biologischer Schädlingsbekämpfung assoziiert.

Das Ziel der vorliegenden Arbeit war die Untersuchung der Auswirkung ackerbaulicher Maßnahmen auf die Unkrautdiversität in Winterweizen und die Evaluierung eines marktbasierten Honorierungssystemes für die Bereitstellung von Unkrautdiversität auf landwirtschaftlichen Flächen. Alle Experimente und Untersuchungen im Rahmen dieser Arbeit wurden in Niedersachsen (Deutschland) durchgeführt.

Anhand eines Praxisversuches in Winterweizen wurde untersucht, wie sich Fruchtfolgeintensität und Unkrautbekämpfung auf die Artenzusammensetzung der Unkrautgesellschaften und den Ertrag des Winterweizens auswirkten. Die Gesamtartenzahl und die Anzahl von Unkrautarten mit Relevanz für höhere trophische Ebenen waren auf Flächen der ökologischen Fruchtfolge deutlich erhöht. Dagegen ließen sich keine signifikanten Unterschiede zwischen Flächen der engen und weiten konventionellen Fruchtfolge feststellen. Dennoch konnte anhand multivariater Redundanzanalysen (RDA) nachgewiesen werden, dass die Fruchtfolgeintensität einen deutlichen Anteil der Varianz innerhalb der Artenzusammensetzung erklärte. Die Gesamtartenzahl sowie die Anzahl der Unkrautarten mit nützlichen Funktionen wurden in den konventionellen Rotationen durch eine Unkrautbekämpfung reduziert, nicht aber in der ökologischen Fruchtfolge. Der Erhalt einer hohen Unkrautdiversität erfordert daher nicht nur eine Erweiterung enger Fruchtfolgen, sondern auch eine Anpassung der jeweiligen Unkrautbekämpfungsstrategien.

Es konnten zudem Herbizide identifiziert werden, die einen selektiven Erhalt konkurrenzschwacher Unkrautarten mit nützlichen ökosystemaren Funktionen (Papaver rhoeas) und seltener Unkrautarten (Centaurea cyanus) bei gleichzeitiger Bekämpfung von konkurrenzstarken Arten (Galium aparine) in Winterweizen ermöglichten. Eine Applikation von Fluroxypyr bzw. Amidosulfuron + Iodosulfuron zeigte hier die vorzüglichste Wirkung. Multivariate Analysen anhand von Principle Response Curves (PRC) deuteten auf eine signifikante Auswirkung der unterschiedlichen 
Herbizidbehandlungen auf die Artenzusammensetzung der untersuchten Unkrautpopulationen hin. Die Wirkung der einzelnen Herbizide auf die Zusammensetzung variierte allerdings abhängig von den betrachteten Arten und den untersuchten Standorten. Die Ergebnisse zeigen, dass die Applikation von selektiven Herbiziden mit geringer Wirkungsbreite eine praktikable Strategie für das Management von Unkrautdiversität in Winterweizen darstellt. Allerdings muss die Auswahl der herbiziden Wirkstoffe standortspezifisch in Abhängigkeit des Auftretens konkurrenzstarker Unkrautarten und damit verbundener Ertragsverluste erfolgen.

Die untersuchte Anpassung der Bewirtschaftungsmaßnahmen an die Förderung der Unkrautdiversität war partiell mit reduzierten Erträgen verbunden. Das Ziel von Agrarumweltprogrammen ist es daher, Landwirte für die Opportunitätskosten zu entschädigen, die ihnen durch den Schutz der Unkrautdiversität entstehen. In diesem Zusammenhang wird davon ausgegangen, dass Honorierungsprogramme wie Zahlungen für Umweltdienstleistungen (payments for environmental services, PES), die auf marktbasierten Instrumenten wie Ausschreibungsverfahren basieren, einen Erhalt von Biodiversität wesentlich kosteneffizienter als derzeitige Programme mit festen Honorierungszahlungen erreichen können. Im Rahmen dieser Arbeit wurde die Implementierung eines marktbasierten PES-Programms zur Förderung der Unkrautdiversität in einer definierten Region evaluiert. In dem untersuchten PESProgramm waren die Honorierungszahlungen an die Erbringung einer ökologischen Dienstleitung gekoppelt, die als eine festgelegte Anzahl von Unkrautarten definiert wurde. In den durchgeführten Ausschreibungsverfahren gaben die Landwirte Gebote mit der Angabe eines Preises ab, zu dem sie bereit waren, die ökologische Dienstleistung auf ihren Flächen zu erbringen. Die Untersuchungen zeigten, dass das PES-Programm erfolgreich zu einer Erhöhung der Unkrautdiversität auf den Flächen der teilnehmenden Landwirte beitragen konnte. Allerdings lagen die Angebotspreise der Landwirte deutlich über ihren jeweiligen Opportunitätskosten. Es muss daher davon ausgegangen werde, dass neben den Opportunitätskosten noch weitere Faktoren wie die Produktionsunsicherheit der ökologischen Dienstleistungen, anfallende Transaktionskosten und die individuelle Einschätzung der Landwirte über den maximal möglichen Angebotspreis auf die Bemessung des Angebotspreises gewirkt haben. Die Bewertung der Kosteneffizienz von PES-Programmen erfordert daher weitere Forschung und Evaluierung. 
In dieser Arbeit konnte gezeigt werden, dass sich die untersuchten Managementstrategien zur Erhöhung der Unkrautdiversität in konventionelle Ackerbausysteme integrieren ließen. Dennoch ist der Erhalt von Unkrautarten mit wichtigen Funktionen im Agrarökosystem vielfach nicht uneingeschränkt mit der Sicherung derzeitiger Ertragslevel zu vereinbaren. Die Schaffung finanzieller Anreize durch PES-Programme ist daher ein wichtiger Schritt hin zu nachhaltigen Ackerbausystemen, die auch den Erhalt einer hohen Unkrautdiversität nicht ausschließen. 


\section{List of Publications}

Peer reviewed journal publications

Ulber, L., Klimek, S., Steinmann, H.-H. \& Isselstein, J. (submitted) Implementing conservation auctions to pay farmers for delivering environmental services.

Ulber, L., Steinmann, H.-H. \& Klimek, S. (2010) Using selective herbicides to manage beneficial and rare weed species in winter wheat. Journal of Plant Diseases and Plant Protection 117, 233-239

Ulber, L., Steinmann, H.-H., Klimek, S. \& Isselstein, J. (2009) An experimental on-farm approach to investigate the impact of diversified crop rotations on weed species richness and composition in winter wheat. Weed Research 49, 534-543

Conference \& workshop proceedings

Ulber, L., Klimek, S., Steinmann, H.-H. \& Isselstein, J. (2010) A market-based payment scheme for conservation of weed species diversity in arable systems. Proceedings of the $15^{\text {th }}$ EWRS symposium Kaposvar/Hungary, 122-123

Ulber, L., Steinmann, H.-H., Klimek, S. \& Isselstein, J. (2010) A market-based payment scheme for plant diversity in farming systems. Aspects of Applied Biology 100, 319326

Ulber, L. \& Steinmann, H.-H. (2010) Honorierung ökologischer Leistungen der Landwirtschaft im Ackerland durch ein Ausschreibungsverfahren. H. Korn, U. Feit (Ed.): Treffpunkt Biologische Vielfalt IX: Interdisziplinärer Forschungsaustausch im Rahmen des Übereinkommens über die biologische Vielfalt - Bonn (Bundesamt für Naturschutz), BfN-Skripten 265, 71-76

Ulber, L., Klimek, S., Steinmann, H.-H. \& Isselstein, J. (2009) Paying farmers for supplying arable weed species diversity in cropping systems. Proceedings of the 39th Annual Conference of the Ecological Society of Germany, Austria and Switzerland (Gfö), p. 88

Ulber, L., Steinmann, H.-H. \& Gerowitt, B. (2009) Rewarding farmers for delivering arable plant diversity - a case-study approach. Proceedings of the $3^{\text {rd }}$ Workshop of the EWRS Working Group 'Weeds and Biodiversity', p. 11 
Ulber, L. \& Steinmann, H.-H. (2008) Influence of crop rotation intensity and weed control treatment on weed species richness and composition in winter wheat fields. Proceedings of the 5th International Weed Science Congress, p. 217

Gerowitt, B., Ulber, L. \& Steinmann, H.-H. (2008) Demanding weeds in arable fields - is it a feasible approach? Proceedings of the 5th International Weed Science Congress, p. 216

Ulber, L., Steinmann, H.-H. \& Isselstein, J. (2008) Unkrautvegetation in Winterweizen unter dem Einfluss von Kulturartendiversität und Bewirtschaftungspraxis. Mitteilungen der Gesellschaft für Pflanzenbauwissenschaften 20, 317-318

Ulber, L. \& Steinmann, H.-H. (2008) Einfluss von Bewirtschaftungspraxis und Kulturartendiversität auf die Unkrautvegetation in Winterweizen. Mitteilungen aus dem Julius-Kühn-Institut 417, p. 398

Bertke, E., Isselstein, J., Klimek, S., Marggraf, R., Müller, B., Sauer, U., Steinmann, H.-H., Stroh, H.-G. \& Ulber, L. (2008) An outcome-based payment scheme rewarding ecological goods in agriculture. CBD Technical Series No. 34: Mainstreaming Biodiversity Issues into Forestry and Agriculture, 3-5.

Bertke, E., Gerowitt, B., Groth, M., Höft, A., Isselstein, J., John, M., Klimek, S., Marggraf, R., Müller, B., Richter gen. Kemmermann, A., Rüffer, C., Sauer, U., Steinmann, H., Stroh, H. G. \& Ulber, L. (2007) The internalising of positive externalities of agriculture with a market based instrument. Verhandlungen der Gesellschaft für Ökologie 37, p. 434 


\section{Acknowledgements}

First, I want to express my grateful thanks to my supervisor Prof. Dr. Johannes Isselstein for providing ideas, constructive feedback, continuous support and encouragement throughout the years. I also wish to acknowledge Prof. Dr. Bärbel Gerowitt for coreviewing my thesis.

My gratitude also goes to Dr. Horst-Henning Steinmann for his support during the planning and realisation of all experiments and manuscripts and sharing his knowledge on plant protection and agro-ecology with me.

My greatest thanks are probably reserved for Dr. Sebastian Klimek who patiently provided me with support regarding virtually all issues related to experimental design, statistical analyses, planning and writing of manuscripts and with constant mental backup throughout his time in Göttingen and Braunschweig.

The field work for this thesis would not have been possible without the substantial help of Kirsi Ahrweiler, Annett Gummert and Dr. Bernd Gehlken. The cooperation of the farmers and their unrestricted willingness to answer numberless questions has also greatly improved the quality of this thesis.

I would like to thank Barbara Edler, Dr. Jan Freese, Hagen Hartmann, Dr. Carsten Mönnig, Dr. Martin Potthoff and Elke Schröder for providing a nice working atmosphere in the Research Centre for Agriculture and the Environment. In addition, I am grateful to all colleagues of associated working groups in Göttingen and Rostock especially Barbara Hohlmann, Maria John, Dr. Stefan Kesting, Stefan Meyer, Dr. Birgit Müller, Dr. Uta Sauer, Melanie Seither, Hans-Georg Stroh, Arne Tichter, Mark Winter \& Dr. Nicole Wrage for co-operation, stimulating discussions and good company. Special thanks also to Barbara Baraibar, Berta Caballero, Suzy Rouphael and Heather Oaten who were great PhD companions during enjoyable official and inofficial meetings around the world.

Finally, my warmest thanks go to all my friends and beloved ones who constantly provided me with support and distraction when it was urgently needed.

This thesis was embedded in the BIOPLEX project funded by the German BMBF and the associated DBU-project "Honorierung ökologischer Leistungen der Landwirtschaft im Ackerland durch ein Ausschreibungsverfahren". 


\section{Curriculum vitae}

Lena Ulber

born 08.12.1981 in Göttingen (Germany)

since 06/2010 Research Associate at the Julius Kühn-Institute (JKI), Federal

Research Centre for Cultivated Plants, Institute for Plant Protection

in Field Crops and Grassland, Braunschweig (Germany)

02/2007-05/2010 PhD Study at the Research Centre for Agriculture and the

Environment, Faculty of Agricultural Sciences, Georg-August-

University Göttingen (Germany) under the supervision of Prof. Dr.

Johannes Isselstein

PhD thesis: "Weed species diversity in cropping systems:

Management and conservation strategies"

12/2004-11/2006 Masters Study in Crop Sciences (M. Sc.) at the HumboldtUniversity Berlin (Germany)

Master thesis (English title): "Variability in reaction of weed species towards herbicides with special regard to herbicide resistance"

06/2005-12/2005 Study abroad at Massey University, Palmerston North (New Zealand)

10/2001-12/2004 Bachelors Study in Agricultural Sciences (B. Sc.) at the Humboldt-University Berlin (Germany)

Bachelor thesis (English title): "Influence of long-term cropping practices (lime and manure application, crop rotation) on yield and selected parameters of seed quality in winter wheat"

$1994-2001$ Secondary Education at Hainberg Gymnasium, Göttingen (Germany) 